\title{
A halocarbon survey from a seagrass dominated subtropical lagoon, Ria Formosa (Portugal): flux pattern and isotopic composition
}

\author{
I. Weinberg, E. Bahlmann, T. Eckhardt, W. Michaelis, and R. Seifert \\ University of Hamburg, Institute for Biogeochemistry and Marine Chemistry, Bundesstraße 55, 20146 Hamburg, Germany \\ Correspondence to: E. Bahlmann (enno.bahlmann@zmaw.de)
}

Received: 1 May 2014 - Published in Biogeosciences Discuss.: 10 July 2014

Revised: 8 January 2015 - Accepted: 20 January 2015 - Published: 17 March 2015

\begin{abstract}
In this study we report fluxes of chloromethane $\left(\mathrm{CH}_{3} \mathrm{Cl}\right)$, bromomethane $\left(\mathrm{CH}_{3} \mathrm{Br}\right)$, iodomethane $\left(\mathrm{CH}_{3} \mathrm{I}\right)$, and bromoform $\left(\mathrm{CHBr}_{3}\right)$ from two sampling campaigns (summer and spring) in the seagrass dominated subtropical lagoon Ria Formosa, Portugal. Dynamic flux chamber measurements were performed when seagrass patches were either air-exposed or submerged. Overall, we observed highly variable fluxes from the seagrass meadows and attributed them to diurnal cycles, tidal effects, and the variety of possible sources and sinks in the seagrass meadows. The highest emissions with up to $130 \mathrm{nmol} \mathrm{m}^{-2} \mathrm{~h}^{-1}$ for $\mathrm{CH}_{3} \mathrm{Br}$ were observed during tidal changes, from air exposure to submergence and conversely. Furthermore, during the spring campaign, the emissions of halocarbons were significantly elevated during tidal inundation as compared to air exposure.

Accompanying water sampling performed during both campaigns revealed elevated concentrations of $\mathrm{CH}_{3} \mathrm{Cl}$ and $\mathrm{CH}_{3} \mathrm{Br}$, indicating productive sources within the lagoon. Stable carbon isotopes of halocarbons from the air and water phase along with source signatures were used to allocate the distinctive sources and sinks in the lagoon. Results suggest that $\mathrm{CH}_{3} \mathrm{Cl}$ was rather originating from seagrass meadows and water column than from salt marshes. Aqueous and atmospheric $\mathrm{CH}_{3} \mathrm{Br}$ was substantially enriched in ${ }^{13} \mathrm{C}$ in comparison to source signatures for seagrass meadows and salt marshes. This suggests a significant contribution from the water phase on the atmospheric $\mathrm{CH}_{3} \mathrm{Br}$ in the lagoon.

A rough global upscaling yields annual productions from seagrass meadows of $2.3-4.5 \mathrm{Gg} \mathrm{yr}^{-1}, 0.5-1.0 \mathrm{Gg} \mathrm{yr}^{-1}, 0.6-$ 1.2 $\mathrm{Gg} \mathrm{yr}^{-1}$, and $1.9-3.7 \mathrm{Gg} \mathrm{yr}^{-1}$ for $\mathrm{CH}_{3} \mathrm{Cl}, \mathrm{CH}_{3} \mathrm{Br}, \mathrm{CH}_{3} \mathrm{I}$, and $\mathrm{CHBr}_{3}$ respectively. This suggests a minor contribution from seagrass meadows to the global production of $\mathrm{CH}_{3} \mathrm{Cl}$ and $\mathrm{CH}_{3} \mathrm{Br}$ with about 0.1 and $0.7 \%$, respectively. In com-
\end{abstract}

parison to the known marine sources for $\mathrm{CH}_{3} \mathrm{I}$ and $\mathrm{CHBr}_{3}$, seagrass meadows are rather small sources.

\section{Introduction}

The halocarbons chloromethane $\left(\mathrm{CH}_{3} \mathrm{Cl}\right)$, bromomethane $\left(\mathrm{CH}_{3} \mathrm{Br}\right)$, iodomethane $\left(\mathrm{CH}_{3} \mathrm{I}\right)$, and bromoform $\left(\mathrm{CHBr}_{3}\right)$ are prominent precursors of reactive halogens, which affect the oxidative capacity of the atmosphere and initiate stratospheric ozone destruction (Saiz-Lopez and von Glasow, 2012, and references therein). Therefore, during the past decades, the sources and sinks of these trace gases have been intensively studied.

For $\mathrm{CH}_{3} \mathrm{Cl}$, recent atmospheric budget calculations suggest that the known sinks can be balanced by large emissions from tropical terrestrial sources (Saito and Yokouchi, 2008; Xiao et al., 2010). Nevertheless, these calculations still incorporate large uncertainties. The atmospheric budget of $\mathrm{CH}_{3} \mathrm{Br}$ still remains unbalanced, with the known sinks exceeding known sources by about $30 \%$ (Yvon-Lewis et al., 2009). The current emission estimates for $\mathrm{CH}_{3} \mathrm{I}$ and $\mathrm{CHBr}_{3}$ are assigned with even larger uncertainties (Bell et al., 2002; Quack and Wallace, 2003).

Stable carbon isotopes of halocarbons have been applied to further elucidate their sources and sinks by using individual source signatures (Keppler et al., 2005). While this was primarily done for $\mathrm{CH}_{3} \mathrm{Cl}$, first isotopic source signatures of naturally-produced $\mathrm{CH}_{3} \mathrm{Br}$ were recently reported (Bill et al., 2002; Weinberg et al., 2013). Moreover, the biogeochemical cycling of halocarbons underlies various transformation processes, which can be studied by the stable carbon isotope 
approach in addition to flux and/or concentration measurements.

Coastal zones are reported as being important source regions of halocarbons. In these salt water affected systems, halocarbon producers comprise phytoplankton (Scarratt and Moore, 1998), macroalgae (Gschwend et al., 1985), salt marshes (Rhew et al., 2000), and mangroves (Manley et al., 2007).

With a net primary production of $1211 \mathrm{~g} \mathrm{C} \mathrm{m}^{-2} \mathrm{yr}^{-1}$, seagrass meadows are one of the most productive ecosystems with a similar global abundance as mangroves and salt marshes (Duarte et al., 2005). They cover huge areas of the intertidal and subtidal zone in temperate and subtropical/tropical regions. Thus, they may represent an additional source for halocarbons to the atmosphere, which is not yet sufficiently studied. Seagrass meadows are highly diverse ecosystems with respect to potential halocarbon producers. Along with the seagrass itself, they comprise epiphytes such as microalgae and diatoms, and sediment reassembling microphytobenthos and bacteria communities. All these constituents of the benthic community have been reported to produce halocarbons (Amachi et al., 2001; Blei et al., 2010; Manley et al., 2006; Moore et al., 1996; Rhew et al., 2002; Tokarczyk and Moore, 1994; Urhahn, 2003). While first evidence for the release of halocarbons from seagrass was obtained by incubation experiments (Urhahn 2003), we could recently confirm this production potential in a field study of a temperate seagrass meadow in northern Germany (Weinberg et al., 2013).

In order to refine these results, we conducted two field campaigns in the subtropical lagoon Ria Formosa, Portugal in 2011 and 2012. Here we report the results of these campaigns comprising dynamic flux chamber measurements for halocarbons over seagrass meadows during air exposure and tidal inundation. Using the flux and isotopic data, we present the first insights into the environmental controls of halocarbon dynamics within this ecosystem.

\section{Materials and methods}

\subsection{Sampling site}

The Ria Formosa, covering an area of $84 \mathrm{~km}^{2}$, is a mesotidal lagoon at the south-eastern coast of the Algarve, Portugal (Fig. 1). It is separated from the Atlantic Ocean by a series of barrier islands and two peninsulas. About $80 \%$ of the lagoon is intertidal with a semi-diurnal tidal regime and tidal ranges between $1.3 \mathrm{~m}$ during neap tides and $3.5 \mathrm{~m}$ during spring tides (Cabaço et al., 2012). Due to negligible inflow of fresh water and high exchange of water with the open Atlantic during each tidal cycle, the salinity within the lagoon is 35 to 36 PSU year round, except for periods of heavy rainfalls. About a quarter of the intertidal area $\left(13.04 \mathrm{~km}^{2}\right)$ is covered by dense stands of Zostera noltii Hornem (Guimarães et al.,

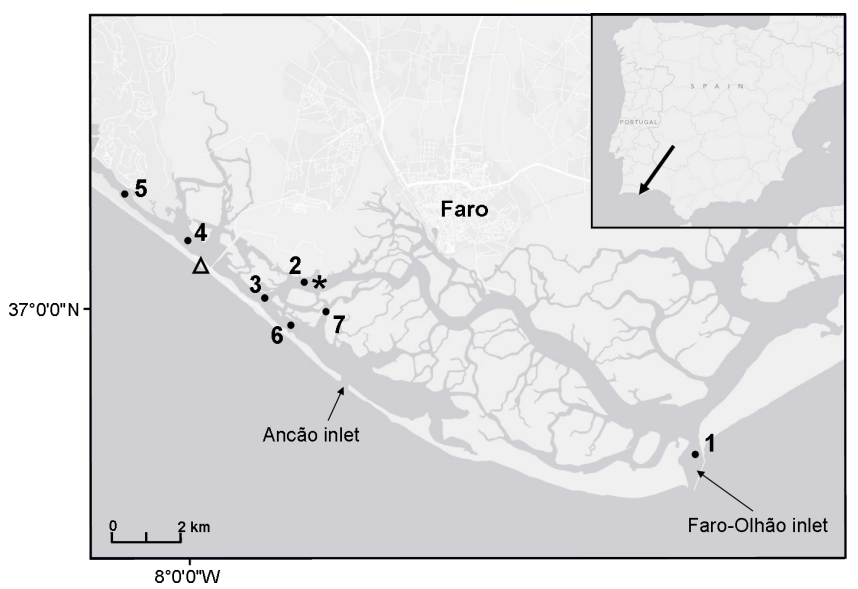

Figure 1. Map of the lagoon Ria Formosa, Portugal. Asterisk: site of seagrass meadow studies; triangle: sampling site on the Praia de Faro (upwind position). Dots with numbers represent sampling points during the transect cruise.

2012). Further, but much less abundant, seagrass species in the lagoon are Zostera Marina L. and Cymodocea nodosa (Ucria) Ascherson, which are mainly located in shallow parts of the subtidal areas (Santos et al., 2004). About $30 \%$ of the lagoon's area is covered with salt marsh communities (R. Santos, personal communication, 2013).

\subsection{Sampling}

We conducted two sampling campaigns in the western part of the lagoon at the Ramalhete research station (Centre of Marine Sciences (CCMAR), Universidade do Algarve) in the vicinity of Faro $\left(37.0^{\circ} \mathrm{N}, 7.6^{\circ} \mathrm{W}\right)$ (Fig. 1). The sampling was carried out from 23 July-7 August 2011 and 17 Apri28 April 2012, coinciding with the beginning (2012 campaign) and peak (2011 campaign) of the seagrass reproductive season. Ambient air temperatures were distinctively different between both campaigns, ranging from 21 to $27^{\circ} \mathrm{C}$ (mean $24^{\circ} \mathrm{C}$ ) with almost entirely clear weather in summer and 13 to $23^{\circ} \mathrm{C}$ (mean $17^{\circ} \mathrm{C}$ ) in spring with frequent strong cloud cover. Mean water temperatures were $25.9^{\circ} \mathrm{C}$ (summer) and $17.5^{\circ} \mathrm{C}$ (spring). The prevailing wind direction during both campaigns was west south-west to with rather low average wind speeds of $4 \mathrm{~m} \mathrm{~s}^{-1}$ during summer and $5 \mathrm{~m} \mathrm{~s}^{-1}$ during spring.

During the two campaigns, we used different dynamic flux chamber systems. During the 2011 campaign, we measured the halocarbon fluxes during air exposure using a quartzglass chamber $\left(0.1 \mathrm{~m}^{2}\right.$ surface area, $7 \mathrm{~L}$ enclosure volume $)$ as described in Weinberg et al. (2013) with some adjustments. For this study, a permanent backup flow $\left(3 \pm 0.2 \mathrm{~L} \mathrm{~min}^{-1}\right)$ through the flux chamber during sampling and the change of cryotraps was applied to ensure sufficient mixing. Further, to overcome analytical problems with the high humidity in the sampled air, the water content was reduced using a condenser 
$\left(-15^{\circ} \mathrm{C}\right)$. Briefly, the quartz-glass flux chamber was placed on the seagrass patch and sealed with surrounding sediment. Two sampling systems were operated simultaneously, measuring inlet and outlet air of the flux chamber (flow rate $1 \pm 0.2 \mathrm{~L} \mathrm{~min}^{-1}$ ). Prior to sampling, the flux chamber was flushed for about 10 min ensuring sufficient equilibration of compounds in the chamber air.

During the 2012 campaign, we used a dynamic flux chamber system $\left(0.037 \mathrm{~m}^{2}\right.$ bottom surface area, $8 \mathrm{~L}$ enclosure volume) suitable for flux measurements during both periods of air exposure and tidal immersion. The properties and setup of this dynamic chamber system is described in detail elsewhere (Bahlmann et al., 2014). Since this system acts as an ordinary purge and trap system, the extraction efficiencies were simulated using halocarbon equilibrated artificial seawater. While the results from these tests revealed that monohalomethanes were almost completely extracted $(\geq 90 \%)$, the purge efficiencies for $\mathrm{CHBr}_{3}$ were only $33 \%$. Thus the reported $\mathrm{CHBr}_{3}$ fluxes determined from seagrass meadows using the submergible chamber system represent an underestimate.

Based on the sampling system for the determination of stable carbon isotopes of halocarbons (Bahlmann et al., 2011), we modified the cryogenic trapping system for the measurements of halocarbon mixing ratios, in order to establish a better temporal resolution by reducing the analysis time. This results in a final air volume of $28 \pm 5 \mathrm{~L}$ of air at the inlet and the outlet of the chambers, respectively. The specifications along with the results from test surveys are given in the Supplement.

The seagrass species sampled was exclusively Z. Noltii. The seagrass patches sampled had an area coverage of $>95 \%$ and were free of visible epiphytes such as macroalgae. In this low to medium intertidal region the epiphytes of Z. Noltii are almost exclusively diatoms, whose contribution ranges from 0.5 to $4 \%$ of the total seagrass biomass (Cabaço et al., 2009). We further determined the fluxes from an adjacent bare sediment spot during the 2011 campaign. On 2 August 2011, these chamber-based measurements were complemented by atmospheric sampling at a nearby beach (Praia de Faro, upwind site) about $3 \mathrm{~km}$ distant from the lagoon during the summer campaign 2011 (Fig. 1). At this time the wind direction was south-westerly, reflecting background air from the coastal ocean.

Discrete water samples for the determination of dissolved halocarbons concentration and isotopic composition at high tide were taken during both campaigns. The samples were taken directly above the studied seagrass meadow using Duran glass bottles ( $1-2 \mathrm{~L}$ volume). Air and sediment intrusions during water sampling were avoided. The water depth was between $0.3 \mathrm{~m}$ and $1 \mathrm{~m}$. On 24 April 2012, a transect cruise through the middle and western part of the lagoon was conducted during rising waters (Fig. 1). The water samples were taken from a water depth of $1 \mathrm{~m}$. Dissolved halocarbons were extracted from seawater using a purge and trap system. Sea- water was purged with helium 5.0 (purge flow $1 \mathrm{~L} \mathrm{~min}^{-1}$ ) for $30 \mathrm{~min}$. After water vapour reduction of the purge gas, the compounds were enriched on cryotraps (submerged in a dry shipper). The shape of the cryotraps used here was the same as those for flux chamber and atmospheric samples. The water samples were usually processed within $30 \mathrm{~min}$ after sampling. Samples from the transect cruise were stored in the dark at $4{ }^{\circ} \mathrm{C}$ and analysed within $8 \mathrm{~h}$. Purge efficiencies of monohalomethanes from lagoon water were $\geq 95 \%$ ( 1 and $2 \mathrm{~L}$ samples). However, the less volatile $\mathrm{CHBr}_{3}$ was only extracted with $50 \%$ (1 L samples) and 30\% (2 L samples). Therefore, the results of water concentration were corrected for the respective purge efficiency for this compound.

\subsection{Measurement and quantification}

The measurement procedure is described in detail in the Supplement. Briefly, compounds adsorbed on the cryotraps were thermally desorbed and transferred to Peltier-cooled adsorption tubes. The analytes were further desorbed from the adsorption tubes and refocused cryogenically before injection to the GC-MS system. Air and water samples were measured on-site at Ramalhete research station using a GC-MS system (6890N/5975B, Agilent, Germany) equipped with a CPPorabondQ column $(25 \mathrm{~m}, 0.25 \mu \mathrm{m}$ i.d., Varian, Germany). The GC-MS was operated in the electron impact mode. Identification of compounds was executed by retention times and respective mass spectra. Aliquots of gas standard (Scott EPA TO 15/17, 65 compounds, $1 \mathrm{ppm}$ each in nitrogen, Sigma Aldrich, Germany) containing $\mathrm{CH}_{3} \mathrm{Cl}, \mathrm{CH}_{3} \mathrm{Br}$, and $\mathrm{CHBr}_{3}$ were applied to quantify the target compounds. During onsite measurements, $\mathrm{CH}_{3} \mathrm{I}$ was quantified using the response factor against $\mathrm{CH}_{3} \mathrm{Br}$. The response factor was determined prior to the campaign. Equivalent amounts of $\mathrm{CH}_{3} \mathrm{I}$ and $\mathrm{CH}_{3} \mathrm{Br}$ from single gas standards were analysed together for the response factor calculation. The analytical limit of detection was $0.3 \mathrm{ppt}\left(\mathrm{pmol} \mathrm{mol}^{-1}\right)$ for the halocarbons. The accuracy of the entire sampling method (sampling, sample treatment, measurement) was derived from test samples in triplicates. The deviation between the individual samples for $\mathrm{CH}_{3} \mathrm{Cl}, \mathrm{CH}_{3} \mathrm{Br}, \mathrm{CH}_{3} \mathrm{I}$, and $\mathrm{CHBr}_{3}$ was $5.4,6.3,15.4$ and $6.7 \%$, respectively. A series of procedural blanks (cryotraps and adsorption tubes) were taken during the sampling campaigns. The occasionally detected blanks of $\mathrm{CH}_{3} \mathrm{Cl}$ and $\mathrm{CH}_{3} \mathrm{Br}$ from these determinations were $\leq 3 \%$ to the "real" samples taken from the seagrass meadows during sampling campaigns. Therefore, the halocarbon fluxes were not blank corrected.

Air and water samples for determining the isotopic composition of halocarbons were transferred to adsorption tubes and stored at $-80^{\circ} \mathrm{C}$ until they were measured. The analysis was conducted using the GC-MS-IRMS system at our home laboratory (Bahlmann et al., 2011). Additional transport and storage blanks were processed, which revealed no contamination for all halocarbons studied. 


\subsection{Calculations}

The fluxes were determined with dynamic flux chambers. The chamber is positioned on the a sampling spot and flushed continuously with ambient air. The mixing ratios of compounds at the inlet and outlet air are then measured. The difference of mixing ratios of compounds between inlet and outlet air along with the flushing rate and the surface area are used for the flux calculation $\left(F_{\mathrm{Net}}, \mathrm{nmol} \mathrm{m}^{-2} \mathrm{~h}^{-1}\right)$ :

$F_{\text {Net }}=\frac{Q \times\left(C_{\text {out }}-C_{\text {in }}\right)}{A \times V \times 1000}$

Here, $Q$ is the flushing rate of air through the chamber $\left(\mathrm{Lh}^{-1}\right), C_{\text {out }}$ and $C_{\text {in }}$ are the mixing ratios of target compounds (ppt) at the outlet and the inlet of the flux chamber. $A$ is the enclosed surface area of the flux chamber $\left(\mathrm{m}^{2}\right)$ and $V$ is the molar volume (L) at $1013.25 \mathrm{mbar}$ and $298.15 \mathrm{~K}$.

For calculation of the sea-air fluxes from the lagoon water, the inlet samples of the flux chamber were used, which reflect the air mixing ratios. Where no corresponding inlet sample was available, the campaign means were applied. After conversion of the air mixing ratios to $\mathrm{pmol} \mathrm{L}^{-1}$ using temperature data and the respective molar volume of the ambient air, the sea-air fluxes $\left(F, \mathrm{nmol} \mathrm{m}^{-2} \mathrm{~h}^{-1}\right)$ of halocarbons were calculated by the equation:

$F=k_{\mathrm{w}} \times\left(C_{\mathrm{w}}-C_{\mathrm{a}} \times H^{-1}\right)$

where $k_{\mathrm{w}}$ is the gas exchange velocity $\left(\mathrm{m} \mathrm{h}^{-1}\right), C_{\mathrm{w}}$ and $C_{\mathrm{a}}$ the water concentration and air concentration $\left(\mathrm{pmol} \mathrm{L}^{-1}\right)$, respectively, and $H$ the dimensionless and temperature dependent Henry's law constant taken from Moore (2000) for $\mathrm{CH}_{3} \mathrm{Cl}$, Elliott and Rowland (1993) for $\mathrm{CH}_{3} \mathrm{Br}$ and $\mathrm{CH}_{3} \mathrm{I}$, and Moore et al. (1995) for $\mathrm{CHBr}_{3}$. Several approximations emerged to estimate the relationship between the gas exchange velocity $k$ and the wind speed $u$ for open and coastal oceans (e.g. Nightingale et al., 2000; Wanninkhof, 1992). These estimations rely on assumptions that trace gas exchange is based on wind-driven turbulence. This is not applicable in shallow estuarine and riverine systems where the sea-air gas exchange is additionally driven by windindependent currents and the bottom turbulence, and thus water depth and current velocities further play a major role (Raymond and Cole, 2001). Studying the sea-air exchange in the Ria Formosa, these additional factors have to be considered in addition to wind driven outgassing. Therefore, we used the parameterisation of $k_{\mathrm{w}}$ with the assumption that wind speed and water current driven turbulence are additive (Borges et al., 2004):

$k_{\mathrm{w}}=1.0+1.719 \times w^{0.5} \times h^{-0.5}+2.58 \times u$

where $w$ is the water current $\left(\mathrm{cm} \mathrm{s}^{-1}\right), h$ the water depth $(\mathrm{m})$ and $u$ the wind speed $\left(\mathrm{m} \mathrm{s}^{-1}\right)$. For the calculations of the sea-air flux in the lagoon, a mean water depth of $1.5 \mathrm{~m}$ (Tett et al., 2003) and a mean water current of $24 \mathrm{~cm} \mathrm{~s}^{-1}$ (Durham,
2000 ) was used. The Schmidt number ( Sc) expresses the ratio of transfer coefficients of the kinematic viscosity of water and gas diffusivity of interest. The gas exchange velocity $k_{\mathrm{W}}$ for each gas was then normalised to a Schmidt number of 660, assuming a proportionality to $S c^{-0.5}$ (Borges et al., 2004). The individual Schmidt numbers were obtained from Tait (1995) for $\mathrm{CH}_{3} \mathrm{Cl}$, De Bruyn and Saltzman (1997) for $\mathrm{CH}_{3} \mathrm{Br}$ and $\mathrm{CH}_{3} \mathrm{I}$, and Quack and Wallace (2003) for $\mathrm{CHBr}_{3}$.

\section{Results}

\subsection{Halocarbons in the atmosphere and lagoon water}

The air mixing ratios in the lagoon were adopted from the inlets of the flux chambers at $1 \mathrm{~m}$ above ground during both campaigns. The results of these measurements and those of the upwind site outside the lagoon (Praia de Faro) are presented in Table 1. In summer, elevated air mixing ratios of the monohalomethanes were observed during periods of easterly winds when air masses at the sampling site had presumably passed over major parts of the lagoon. These mixing ratios reached up to $1490 \mathrm{ppt}$ for $\mathrm{CH}_{3} \mathrm{Cl}, 61 \mathrm{ppt}$ for $\mathrm{CH}_{3} \mathrm{Br}$, and $11 \mathrm{ppt}$ for $\mathrm{CH}_{3} \mathrm{I}$, reflecting a potent source in this system. The mixing ratios at the upwind site (Praia de Faro) were distinctively lower with mean values of $613 \mathrm{ppt}\left(\mathrm{CH}_{3} \mathrm{Cl}\right), 13 \mathrm{ppt}$ $\left(\mathrm{CH}_{3} \mathrm{Br}\right), 1 \mathrm{ppt}\left(\mathrm{CH}_{3} \mathrm{I}\right)$, and $8 \mathrm{ppt}\left(\mathrm{CHBr}_{3}\right)$, further indicating a source inside the lagoon. In spring 2012, the mean air mixing ratios in the lagoon were significantly lower than during summer with $654 \mathrm{ppt}$ for $\mathrm{CH}_{3} \mathrm{Cl}, 12 \mathrm{ppt}$ for $\mathrm{CH}_{3} \mathrm{Br}, 1 \mathrm{ppt}$ for $\mathrm{CH}_{3} \mathrm{I}$, and $2 \mathrm{ppt}$ for $\mathrm{CHBr}_{3}$.

Discrete water samples were taken above the studied seagrass meadow during tidal inundation (summer $n=9$; spring $n=10$ ). The results are presented in Table 1 . In summer, concentrations ranged from 158 to $301 \mathrm{pmol} \mathrm{L}^{-1}\left(\mathrm{CH}_{3} \mathrm{Cl}\right)$, 5 to $11 \mathrm{pmol} \mathrm{L}^{-1}\left(\mathrm{CH}_{3} \mathrm{Br}\right), 4$ to $18 \mathrm{pmol} \mathrm{L}^{-1}\left(\mathrm{CH}_{3} \mathrm{I}\right)$, and 67 to $194 \mathrm{pmol} \mathrm{L}^{-1}\left(\mathrm{CHBr}_{3}\right)$. During the spring campaign, the water concentrations were 101 to $267 \mathrm{pmol} \mathrm{L}^{-1}$ for $\mathrm{CH}_{3} \mathrm{Cl}$, 6 to $28 \mathrm{pmol} \mathrm{L}^{-1}$ for $\mathrm{CH}_{3} \mathrm{Br}, 2$ to $16 \mathrm{pmol} \mathrm{L}^{-1}$ for $\mathrm{CH}_{3} \mathrm{I}$, and 39 to $133 \mathrm{pmol} \mathrm{L}^{-1}$ for $\mathrm{CHBr}_{3}$.

The results obtained from samples of the transect cruise covered in 2012 (Fig. 1) are given in Table 2. We observed an approximate two-fold increase of concentration for $\mathrm{CH}_{3} \mathrm{Cl}$ (from 121 to $241 \mathrm{pmol} \mathrm{L}^{-1}$ ) and $\mathrm{CHBr}_{3}$ (from 26 to $55 \mathrm{pmol} \mathrm{L}^{-1}$ ) between position 1 (Faro-Olhão inlet) and position 2 (near to the seagrass meadows studied). The increase was less pronounced for $\mathrm{CH}_{3} \mathrm{Br}$ (5 to $7 \mathrm{pmol} \mathrm{L}^{-1}$ ) and not notable for $\mathrm{CH}_{3} \mathrm{I}$. The seawater at positions 6 and 7, the nearest to the Ancão inlet, revealed rather low concentrations for all compounds. We further observed rising concentrations for all halocarbons along positions 3, 4, and 5 with increasing distance to the Ancão inlet. They increased from 96 to $180 \mathrm{pmol} \mathrm{L}^{-1}$ for $\mathrm{CH}_{3} \mathrm{Cl}$, from 9 to $19 \mathrm{pmol} \mathrm{L}^{-1}$ for $\mathrm{CH}_{3} \mathrm{Br}, 2$ to $14 \mathrm{pmol} \mathrm{L}^{-1}$ for $\mathrm{CH}_{3} \mathrm{I}$, and 21 to $95 \mathrm{pmol} \mathrm{L}^{-1}$ for $\mathrm{CHBr}_{3}$. 
Table 1. Summary of air mixing ratios and water concentrations of halocarbons in the Ria Formosa and at the background site (Praia de Faro) for the sampling campaigns in summer 2011 and spring 2012. Values are given as means (bold) and ranges (in parentheses). Samples from the Ria Formosa are data from the inlet of the flux chambers with a sampling height of $1 \mathrm{~m}$ above ground (summer: $n=36$; Praia de Faro: $n=5$; spring $n=47$ ). Given water concentrations refer to $n=8$ (summer) and $n=10$ (spring).

\begin{tabular}{|c|c|c|c|}
\hline & $\begin{array}{l}\text { Air mixing ratio } \\
\text { Ria Formosa (ppt) }\end{array}$ & $\begin{array}{l}\text { Air mixing ratio } \\
\text { Praia de Faro (ppt) }\end{array}$ & $\begin{array}{l}\text { Water concentration } \\
\text { Ria Formosa }\left(\mathrm{pmol} \mathrm{L}^{-1}\right)\end{array}$ \\
\hline \multicolumn{4}{|c|}{ Summer 2011} \\
\hline $\mathrm{CH}_{3} \mathrm{Cl}$ & $828(503-1490)$ & $\mathbf{6 1 3}(498-685)$ & $220(158-301)$ \\
\hline $\mathrm{CH}_{3} \mathrm{Br}$ & $22(8-118)$ & $13(9-19)$ & $8(5-11)$ \\
\hline $\mathrm{CH}_{3} \mathrm{I}$ & $3(2-11)$ & $\mathbf{1}(0.8-2)$ & $12(4-18)$ \\
\hline $\mathrm{CHBr}_{3}$ & $15(6-31)$ & $8(6-9)$ & $102(67-194)$ \\
\hline \multicolumn{4}{|c|}{ Spring 2012} \\
\hline $\mathrm{CH}_{3} \mathrm{Cl}$ & $654(484-976)$ & - & $166(101-267)$ \\
\hline $\mathrm{CH}_{3} \mathrm{Br}$ & $12(4-40)$ & - & $10(6-28)$ \\
\hline $\mathrm{CH}_{3} \mathrm{I}$ & $1(0.4-4.8)$ & - & $7(2-16)$ \\
\hline $\mathrm{CHBr}_{3}$ & $2(0.4-10)$ & - & $62(39-133)$ \\
\hline
\end{tabular}

Table 2. Water concentration ( $\mathrm{pmolL}^{-1}$ ) and stable carbon isotope ratios of halocarbons (\%o) obtained from a $2 \mathrm{~h}$ transect cruise on 24 April 2012 (see Fig. 1 for sampling positions).

\begin{tabular}{|c|c|c|c|c|c|c|c|c|c|}
\hline Sample & $\begin{array}{l}\text { Time } \\
\text { (local) }\end{array}$ & $\begin{array}{l}\mathrm{CH}_{3} \mathrm{Cl} \\
\text { pmolL }^{-1}\end{array}$ & $\%$ & $\begin{array}{l}\mathrm{CH}_{3} \mathrm{Br} \\
\text { pmolL }^{-1}\end{array}$ & $\%$ & $\begin{array}{l}\mathrm{CH}_{3} \mathrm{I} \\
\mathrm{pmolL}^{-1}\end{array}$ & $\%$ & $\begin{array}{l}\mathrm{CHBr}_{3} \\
\mathrm{pmolL}^{-1}\end{array}$ & $\%$ \\
\hline 1 & $15: 09$ & 121 & -40.9 & 5 & -25.6 & 5 & -20.0 & 26 & -25.8 \\
\hline 2 & $15: 50$ & 241 & -42.3 & 7 & -21.2 & 5 & -31.1 & 55 & -18.3 \\
\hline 3 & $15: 58$ & 96 & - & 9 & - & 2 & - & 21 & - \\
\hline 4 & $16: 10$ & 106 & - & 11 & - & 5 & - & 31 & - \\
\hline 5 & $16: 21$ & 180 & -44.3 & 19 & -35.9 & 14 & -44.5 & 95 & -18.9 \\
\hline 6 & $16: 46$ & 72 & - & 5 & - & 3 & - & 18 & - \\
\hline 7 & $16: 50$ & 82 & - & 4 & - & 5 & - & 14 & - \\
\hline
\end{tabular}

\subsection{Fluxes from seagrass meadows, sediment, and sea-air exchange}

The mean fluxes and ranges of $\mathrm{CH}_{3} \mathrm{Cl}, \mathrm{CH}_{3} \mathrm{Br}, \mathrm{CH}_{3} \mathrm{I}$, and $\mathrm{CHBr}_{3}$ from seagrass meadows, sediment, and from sea-air exchange calculations obtained from the two sampling campaigns are given in Table 3.

During the summer campaign (air exposure), we observed highly variable emission and deposition fluxes ranging from -49 to $74 \mathrm{nmol} \mathrm{m}^{-2} \mathrm{~h}^{-1}$ and -5.7 to $130 \mathrm{nmol} \mathrm{m}^{-2} \mathrm{~h}^{-1}$ for $\mathrm{CH}_{3} \mathrm{Cl}$ and $\mathrm{CH}_{3} \mathrm{Br}$, respectively. The variability was less pronounced for $\mathrm{CH}_{3} \mathrm{I}\left(0.5\right.$ to $\left.2.8 \mathrm{nmol} \mathrm{m}^{-2} \mathrm{~h}^{-1}\right)$ and $\mathrm{CHBr}_{3}$ ( -0.6 to $5.7 \mathrm{nmol} \mathrm{m}^{-2} \mathrm{~h}^{-1}$ ) where predominantly emissions were measured. Strongly elevated fluxes up to $130 \mathrm{nmol} \mathrm{m}^{-2} \mathrm{~h}^{-1}$ for $\mathrm{CH}_{3} \mathrm{Br}$ were recorded in conjunction with tidal change, from air exposure to inundation and conversely. These high fluxes were substantiated by a concurrent enhanced atmospheric mixing ratio, ranging from 23 to $118 \mathrm{ppt}$ (campaign median $14 \mathrm{ppt}$ ). Omitting these compound-specific tidal phenomena, the fluxes of $\mathrm{CH}_{3} \mathrm{Cl}$ and $\mathrm{CH}_{3} \mathrm{Br}$ were positively correlated $\left(R^{2} 0.55, p<0.05\right)$. There were no significant correlations between $\mathrm{CH}_{3} \mathrm{I}$ and
$\mathrm{CHBr}_{3}$ and the other investigated halocarbons. Due to the inherent high variability of the fluxes, halocarbon fluxes were poorly correlated with solar radiation $\left(R^{2} \leq 0.20\right)$.

The flux chamber measurements over the sediment during air exposure predominantly revealed emissions of all four halocarbons $(n=5)$. These fluxes were: $3.6 \pm 4.3 \mathrm{nmol} \mathrm{m}^{-2} \mathrm{~h}^{-1} \quad\left(\mathrm{CH}_{3} \mathrm{Cl}\right) ; 0.6 \pm 0.5 \mathrm{nmol} \mathrm{m}^{-2} \mathrm{~h}^{-1}$ $\left(\mathrm{CH}_{3} \mathrm{Br}\right) ; \quad 0.3 \pm 0.2 \mathrm{nmol} \mathrm{m}^{-2} \mathrm{~h}^{-1} \quad\left(\mathrm{CH}_{3} \mathrm{I}\right) ; \quad$ and $0.8 \pm 1.0 \mathrm{nmol} \mathrm{m}^{-2} \mathrm{~h}^{-1}\left(\mathrm{CHBr}_{3}\right)$. Except for $\mathrm{CH}_{3} \mathrm{I}$, the halocarbon fluxes were statistically significant different from zero (Mann-Whitney- $U$ test; $p<0.05$ ). Hence, the bare sediment may contribute to the overall emissions above the seagrass by about 10 to $20 \%$ for $\mathrm{CH}_{3} \mathrm{Cl}$ and $\mathrm{CH}_{3} \mathrm{Br}$, and $45 \%$ for $\mathrm{CHBr}_{3}$.

During the 2012 spring campaign, the halocarbon fluxes from seagrass meadows were determined during both periods of air exposure and periods of tidal immersion. Furthermore, the measurements were complemented by other trace gases including hydrocarbons and sulphur containing compounds (Bahlmann et al., 2014). As in the summer campaign, the seagrass meadows were a net source for all halocarbons studied, but on a lower level. The in- 
Table 3. Mean net fluxes (bold) and ranges of halocarbons from flux chamber experiments seagrass meadows and sediments, as well as those from sea-air exchange calculations. Data were obtained during the summer 2011 and spring 2012 campaigns in the Ria Formosa.

\begin{tabular}{lccccc}
\hline & $n$ & $\begin{array}{c}\mathrm{CH}_{3} \mathrm{Cl} \\
\mathrm{nmol} \mathrm{m}^{-2} \mathrm{~h}^{-1}\end{array}$ & $\begin{array}{c}\mathrm{CH}_{3} \mathrm{Br} \\
\mathrm{nmol} \mathrm{m} \mathrm{h}^{-1}\end{array}$ & $\begin{array}{c}\mathrm{CH}_{3} \mathrm{I} \\
\mathrm{nmol} \mathrm{m}^{-2} \mathrm{~h}^{-1}\end{array}$ & $\begin{array}{c}\mathrm{CHBr}_{3} \\
\mathrm{nmol} \mathrm{m}^{-2} \mathrm{~h}^{-1}\end{array}$ \\
\hline $\begin{array}{l}\text { Summer 2011 } \\
\text { Air exposure }\end{array}$ & 28 & $\mathbf{1 5 . 6}(-49.3-74.0)$ & $\mathbf{6 . 5}(-5.7-129.8)$ & $\mathbf{1 . 2}(0.5-2.8)$ & $\mathbf{1 . 8}(-0.6-5.7)$ \\
Air exposure (sediment) & 5 & $\mathbf{3 . 6}(-1.9-8.1)$ & $\mathbf{0 . 6}(-0.2-1.1)$ & $\mathbf{0 . 3}(0.1-0.6)$ & $\mathbf{0 . 8}(-0.3-1.9)$ \\
Sea-air exchange & 8 & $\mathbf{2 9 . 8}(12.8-44.7)$ & $\mathbf{1 . 3}(0.6-1.7)$ & $\mathbf{2 . 2}(0.5-3.2)$ & $\mathbf{4 . 7}(1.0-8.0)$ \\
\hline Spring 2012 & & & & & \\
Air exposure & 17 & $\mathbf{1 . 0}(-29.6-69.0)$ & $\mathbf{0 . 4}(-0.8-3.9)$ & $\mathbf{0 . 6}(-0.6-2.6)$ & $\mathbf{0 . 4}(-0.5-1.3)$ \\
Tidal inundation & 18 & $\mathbf{1 6 . 6}(-58.3-99.7)$ & $\mathbf{1 . 8}(-1.6-8.3)$ & $\mathbf{1 . 9}(0.1-8.0)$ & $\mathbf{3 . 0}(-0.4-10.6)$ \\
$\quad$ tidal change & 5 & $\mathbf{4 0 . 1}(-14.2-99.7)$ & $\mathbf{2 . 7}(0.1-8.3)$ & $\mathbf{3 . 3}(0.1-8.0)$ & $\mathbf{2 . 9}(0.2-10.6)$ \\
$\quad$ incoming tide & 6 & $\mathbf{1 1 . 4}(-14.7-36.6)$ & $\mathbf{1 . 8}(0.2-3.3)$ & $\mathbf{1 . 6}(0.1-2.9)$ & $\mathbf{2 . 8}(0.2-5.1)$ \\
$\quad$ tidal maximum & 2 & $-18.1,-58.3$ & $-0.5,-1.6$ & $0.1,0.1$ & $0.5,-0.1$ \\
$\quad$ ebb flow & 5 & $\mathbf{2 1 . 3}(-13.5-46.2)$ & $\mathbf{2 . 1}(0.1-4.4)$ & $\mathbf{1 . 5}(0.2-3.0)$ & $\mathbf{4 . 5}(-0.4-8.6)$ \\
Sea-air exchange & 10 & $\mathbf{1 5 . 2}(3.5-32.2)$ & $\mathbf{1 . 4}(0.5-4.1)$ & $\mathbf{1 . 3}(0.3-3.7)$ & $\mathbf{8 . 3}(3.8-23.8)$ \\
\hline
\end{tabular}

dividual ranges of air exposure measurements were: -30 to $69 \mathrm{nmol} \mathrm{m}^{-2} \mathrm{~h}^{-1}\left(\mathrm{CH}_{3} \mathrm{Cl}\right) ;-0.8$ to $3.9 \mathrm{nmol} \mathrm{m}^{-2} \mathrm{~h}^{-1}$ $\left(\mathrm{CH}_{3} \mathrm{Br}\right) ;-0.6$ to $2.6 \mathrm{nmol} \mathrm{m}^{-2} \mathrm{~h}^{-1}\left(\mathrm{CH}_{3} \mathrm{I}\right)$; and -0.5 to $1.3 \mathrm{nmol} \mathrm{m}^{-2} \mathrm{~h}^{-1}\left(\mathrm{CHBr}_{3}\right)$. On average, the seagrass meadows were a net source also under submerged conditions ranging from: -58 to $100 \mathrm{nmol} \mathrm{m}^{-2} \mathrm{~h}^{-1}$ for $\mathrm{CH}_{3} \mathrm{Cl} ;-1.6$ to $8.3 \mathrm{nmol} \mathrm{m}^{-2} \mathrm{~h}^{-1}$ for $\mathrm{CH}_{3} \mathrm{Br}$; 0.1 to $8.0 \mathrm{nmol} \mathrm{m}^{-2} \mathrm{~h}^{-1}$ for $\mathrm{CH}_{3} \mathrm{I}$; and -0.4 to $10.6 \mathrm{nmol} \mathrm{m}^{-2} \mathrm{~h}^{-1}$ for $\mathrm{CHBr}_{3}$. Due to the low purge efficiency of $\mathrm{CHBr}_{3}$ during high tide measurements, the fluxes determined with the submergible chamber are underestimated for this compound. Despite this high variability in production/decomposition during air exposure and inundation, the monohalomethanes were significantly correlated to each other $\left(R^{2} \geq 0.50\right)$. These correlations were enhanced compared to those found when the seagrass meadows were air-exposed $\left(R^{2} \geq 0.56\right)$. In this case, only $\mathrm{CH}_{3} \mathrm{I}$ and $\mathrm{CH}_{3} \mathrm{Br}$ were significantly correlated $\left(R^{2} 0.51\right)$. $\mathrm{CHBr}_{3}$ was only slightly correlated to the monohalomethanes.

While deposition fluxes of $\mathrm{CH}_{3} \mathrm{Cl}$ and $\mathrm{CH}_{3} \mathrm{Br}$ of airexposed seagrass meadows occurred predominantly during periods of low irradiance in summer, no obvious relation to the time of day and/or solar radiation was observed during spring, when deposition fluxes were frequently detected. For $\mathrm{CH}_{3} \mathrm{I}$ and $\mathrm{CHBr}_{3}$, uptake was only occasionally observed and situations of emission clearly dominated.

As in the summer campaign, we observed some remarkable tidal effects on halocarbon fluxes during the spring campaign. Firstly, the highest fluxes of all halocarbons were measured when the lagoon water was just reaching the sampling site. Occasionally this was also observed from air exposure to tidal inundation, although less pronounced. However, these short-timed effects were not as strong as during the summer campaign. Secondly, at tidal maximum we observed deposition fluxes for $\mathrm{CH}_{3} \mathrm{Cl}$ and $\mathrm{CH}_{3} \mathrm{Br}$ and deposition fluxes or very weak emissions for $\mathrm{CH}_{3} \mathrm{I}$ and $\mathrm{CHBr}_{3}$. Before and af- ter this period, emission fluxes during incoming tide and ebb flow dominated.

The lagoon water was a net source for all investigated halocarbons to the atmosphere during both campaigns. In summer, the flux ranges were: 13$45 \mathrm{nmol} \mathrm{m}^{-2} \mathrm{~h}^{-1}\left(\mathrm{CH}_{3} \mathrm{Cl}\right) ; 0.6-1.7 \mathrm{nmol} \mathrm{m}^{-2} \mathrm{~h}^{-1}\left(\mathrm{CH}_{3} \mathrm{Br}\right)$; $0.5-3.2 \mathrm{nmol} \mathrm{m}^{-2} \mathrm{~h}^{-1}\left(\mathrm{CH}_{3} \mathrm{I}\right)$; and $1.0-8.0 \mathrm{nmol} \mathrm{m}^{-2} \mathrm{~h}^{-1}$ $\left(\mathrm{CHBr}_{3}\right)$. The respective fluxes in spring were $3.5-$ $32 \quad\left(\mathrm{CH}_{3} \mathrm{Cl}\right), 0.5-4.1 \quad\left(\mathrm{CH}_{3} \mathrm{Br}\right), 0.3-3.7 \quad\left(\mathrm{CH}_{3} \mathrm{I}\right), \quad 3.8-$ $24 \mathrm{a}, \mathrm{nmol} \mathrm{m}^{-2} \mathrm{~h}^{-1}\left(\mathrm{CHBr}_{3}\right)$.

\subsection{Stable carbon isotopes of halocarbons}

Stable carbon isotope ratios of halocarbons were determined for selected samples of both campaigns (Table 4). Isotopic source signatures from seagrass meadows for $\mathrm{CH}_{3} \mathrm{Cl}$ and $\mathrm{CH}_{3} \mathrm{Br}$ were calculated using a coupled isotope and mass balance without integration of a possible sink function (Weinberg et al., 2013).

In 2011, the difference in atmospheric mixing ratios of $\mathrm{CH}_{3} \mathrm{Cl}$ and $\mathrm{CH}_{3} \mathrm{Br}$ between within the lagoon and the upwind position (Praia de Faro) was accompanied by a shift of $\delta^{13} \mathrm{C}$ values. More ${ }^{13} \mathrm{C}$ depleted values were found for $\mathrm{CH}_{3} \mathrm{Cl}$ in the lagoon $(-42 \pm 2 \%$ o compared to the upwind position $\left(-39 \pm 0.4 \%\right.$ ). In contrast, the $\delta^{13} \mathrm{C}$ values of $\mathrm{CH}_{3} \mathrm{Br}$ were significantly enriched in ${ }^{13} \mathrm{C}$ by about $10 \%$ o inside the lagoon $(-29 \pm 5 \%$ ) as compared to the upwind site $(-38 \pm 3)$. These $\delta^{13} \mathrm{C}$ values found in air samples in the lagoon roughly correspond to the $\delta^{13} \mathrm{C}$ values of $\mathrm{CH}_{3} \mathrm{Cl}$ $(-43 \pm 3 \% o)$ and $\mathrm{CH}_{3} \mathrm{Br}(-23 \pm 3 \%$ ) found in samples of lagoon waters.

Atmospheric $\mathrm{CH}_{3} \mathrm{Cl}$ and $\mathrm{CH}_{3} \mathrm{Br}$ were on average more enriched in ${ }^{13} \mathrm{C}$ in spring than in summer by 4 and $6 \%$, respectively. While the $\delta^{13} \mathrm{C}$ values of $\mathrm{CH}_{3} \mathrm{Cl}$ in the lagoon water were quite similar between both periods of the year, those of $\mathrm{CH}_{3} \mathrm{Br}$ were on average more depleted in ${ }^{13} \mathrm{C}$ during spring, 
Table 4. Compilation of stable carbon isotope values of halocarbons (\%) from the two sampling campaigns. Source signatures of seagrass meadows were calculated using a coupled mass and isotope balance (Weinberg et al., 2013).

\begin{tabular}{|c|c|c|c|c|c|c|c|c|}
\hline & $\begin{array}{c}\text { Atmosphere } \\
\text { Ria Formosa } \\
(\% o)\end{array}$ & $n$ & $\begin{array}{c}\text { Atmosphere } \\
\text { Praia de Faro } \\
\qquad(\% o)\end{array}$ & $n$ & Lagoon water & $n$ & $\begin{array}{c}\text { Source signature } \\
\text { Seagrass meadow } \\
(\% o)\end{array}$ & $n$ \\
\hline \multicolumn{9}{|c|}{ Summer 2011} \\
\hline $\mathrm{CH}_{3} \mathrm{Cl}$ & $-42 \pm 2$ & 7 & $-39 \pm 0.4$ & 5 & $-43 \pm 3$ & 7 & $-51 \pm 6$ & 5 \\
\hline $\mathrm{CH}_{3} \mathrm{Br}$ & $-29 \pm 5$ & 7 & $-38 \pm 3$ & 5 & $-23 \pm 3$ & 7 & $-42 \pm 17$ & 4 \\
\hline $\mathrm{CH}_{3} \mathrm{I}$ & - & - & - & - & $-39 \pm 9$ & 7 & - & - \\
\hline $\mathrm{CHBr}_{3}$ & - & - & - & - & $-13 \pm 1$ & 7 & - & - \\
\hline \multicolumn{9}{|c|}{ Spring 2012} \\
\hline $\mathrm{CH}_{3} \mathrm{Cl}$ & $-38 \pm 1$ & 3 & - & - & $-42 \pm 1$ & 5 & $-56 \pm 2$ & 3 \\
\hline $\mathrm{CH}_{3} \mathrm{Br}$ & $-23 \pm 10$ & 3 & - & - & $-33 \pm 8$ & 5 & $-26 ;-33$ & 2 \\
\hline $\mathrm{CH}_{3} \mathrm{I}$ & - & - & - & - & $-37 \pm 7$ & 5 & - & \\
\hline $\mathrm{CHBr}_{3}$ & - & - & - & - & $-18 \pm 1$ & 5 & - & \\
\hline
\end{tabular}

suggesting certain changes in production/decomposition processes. The isotopic composition of $\mathrm{CH}_{3} \mathrm{I}$ in lagoon water was quite similar between summer $(-39 \pm 9 \%$ ) and spring (mean $-37 \pm 7 \%$ ). As for $\mathrm{CH}_{3} \mathrm{Br}$, the $\delta^{13} \mathrm{C}$ values of $\mathrm{CHBr}_{3}$ were more enriched in ${ }^{13} \mathrm{C}$ in summer when compared with those of the spring campaign.

The difference in concentration along the transect cruise was accompanied by variations in the carbon isotopic composition of all compounds (Table 1, Fig. 2). The most ${ }^{13} \mathrm{C}$ depleted values of $\mathrm{CH}_{3} \mathrm{Cl}, \mathrm{CH}_{3} \mathrm{Br}$, and $\mathrm{CH}_{3} \mathrm{I}$ were detected at the position furthest from the inlet. Interestingly, $\mathrm{CHBr}_{3}$ showed the opposite trend with more ${ }^{13} \mathrm{C}$ enriched values in the lagoon $(-25.8 \%$ vs. $\sim-18 \%$ ).

Using the fluxes and $\delta^{13} \mathrm{C}$ values from the inlet and outlet of the flux chamber, we were able to calculate the source signatures of seagrass covered areas. The resulting source signatures of $\mathrm{CH}_{3} \mathrm{Cl}$ from seagrass meadows were similar during both campaigns ( $-51 \pm 6$ and $-56 \pm 2 \%$, respectively) and independent from the strength of emission. For $\mathrm{CH}_{3} \mathrm{Br}$, we observed most depleted $\delta^{13} \mathrm{C}$ values of -53 and $-58 \%$ at increased emission fluxes in summer, but values of -26 and $-29 \%$ during periods of low emission. This corroborates the findings of isotopically heavy $\mathrm{CH}_{3} \mathrm{Br}$ produced within the seagrass meadows $(-29 \%$ ) in spring 2012 , when all samples analysed for the isotopic composition were taken at situations of low emission.

\section{Discussion}

\subsection{Dissolved halocarbons}

A comparison of halocarbon concentrations in the lagoon water to other measurements of the coastal Atlantic found in the literature is displayed in Table 5. The lagoon waters appeared to be highly enhanced in $\mathrm{CH}_{3} \mathrm{Cl}$. Except for one early study of Tait et al. (1994), our measurements gave the most elevated concentrations for this compound. Enhanced concentrations in the lagoon waters were also found for $\mathrm{CH}_{3} \mathrm{Br}$. Given the mean concentrations from other coastal Atlantic studies (Baker et al., 1999; Carpenter et al., 2000; Hu et al., 2010), we recorded higher concentration by a factor of 2 to 3 at our sampling site. The average water concentrations in the lagoon of $\mathrm{CH}_{3} \mathrm{I}$ were in the same range as reported from other parts of the Atlantic (Moore and Groszko 1999; Zhou et al., 2005). However, especially those regions where macroalgae are the dominating source organisms possess higher maximum values (Bravo-Lineares and Mudge, 2009; Jones et al., 2009). This is even more pronounced for $\mathrm{CHBr}_{3}$, for which the seawater concentration within or in the vicinity of macroalgae beds are strongly elevated (BravoLineares and Mudge, 2009; Carpenter et al., 2000; Jones et al., 2009). The area occupied by the prevalent macroalgae species Enteromorpha spp. and Ulva spp. in the Ria Formosa is estimated to be $2.5 \mathrm{~km}^{2}$ (Duarte et al., 2008), considerably below that of other abundant sources such as seagrass meadows. We cannot exclude that phytoplankton contributes significantly to the water concentration of halocarbons, but the predominantly low chlorophyll concentrations $(3.06 \mu \mathrm{g} \mathrm{L}-1$ from long-term measurements, Brito et al., 2012) and low water volumes seem to limit the impact from this source.

Despite the short residence time of the lagoon water masses, of which $50-75 \%$ is exchanged during one tidal cycle (Brito et al., 2010), the transect cruise along the main channels revealed a successive enrichment of halocarbon concentration in the water with increasing distance from the main inlets (Fig. 1 and Table 2). Therefore, the net halocarbon production in the lagoon appears to clearly exceed that outside the lagoon. This is supported by the distinctively increased air mixing ratios of halocarbons in the lagoon as compared to the upwind site (Table 1). 
Table 5. Mean concentrations (bold) and ranges of dissolved halocarbons (pmolL ${ }^{-1}$ ) from the subtropical lagoon Ria Formosa in summer $2011(n=9)$ and spring $2012(n=10)$ in comparison to published data from coastal Atlantic waters.

\begin{tabular}{lllll}
\hline Location & $\mathrm{CH}_{3} \mathrm{Cl}$ & $\mathrm{CH}_{3} \mathrm{Br}$ & $\mathrm{CH}_{3} \mathrm{I}$ & $\mathrm{CHBr}_{3}$ \\
\hline Faro, Portugal (summer) $^{1}$ & $\mathbf{2 2 0}(158-301)$ & $\mathbf{8}(5-11)$ & $\mathbf{1 2}(4-18)$ & $\mathbf{1 0 2}(66-194)$ \\
Faro, Portugal (spring) $^{1}$ & $\mathbf{1 6 6}(101-267)$ & $\mathbf{1 0}(6-28)$ & $\mathbf{7}(2-16)$ & $\mathbf{6 2}(39-133)$ \\
& & & & \\
East Atlantic $^{2, \#}$ & - & - & - & $\mathbf{6 8 . 3}(36.6-102.0)$ \\
Roscoff, France $^{3, \#}$ & - & - & $\mathbf{1 2 . 9}(9.0-31.8)$ & $\mathbf{2 1 7 . 4}(124.8-519.4)$ \\
Greenland, NW Atlantic $^{4}$ & $104-260$ & - & $0.2-16.1$ & - \\
Norfolk, UK $^{5}$ & - & $\mathbf{3 . 2}(1.7-8.7)$ & - & - \\
Menai Strait, UK $^{6, \#}$ & - & - & $\mathbf{6 . 7}(0.0-80.0)$ & $\mathbf{2 1 4 . 2}(3.0-3588.4)$ \\
Mace Head, Ireland $^{7, \#}$ & - & $\mathbf{3 . 7}(1.7-5.7)$ & $\mathbf{1 5 . 3}(10.9-19.2)$ & $\mathbf{3 8 8 . 0}(221.8-554.3)$ \\
West Atlantic $^{8}$ & $\mathbf{8 8 . 4}(61.5-179.0)$ & $\mathbf{1 . 9}(0.8-5)$ & - & - \\
North West Atlantic $^{9}$ & $\mathbf{7 1 . 0}(55.0-106.0)$ & - & - & - \\
Nova Scotia, Canada $^{10}$ & - & - & $4-6$ & - \\
Gulf of Maine, UK $^{11, \#}$ & - & - & $8-18$ & $40-1240$ \\
\hline
\end{tabular}

${ }^{1}$ This study; ${ }^{2}$ Carpenter et al. (2009); ${ }^{3}$ Jones et al. (2009); ${ }^{4}$ Tait et al. (1994); ${ }^{5}$ Baker et al. (1999); ${ }^{6}$ Bravo-Linares and Mudge (2009);

${ }^{7}$ Carpenter et al. (2000); ${ }^{8}$ Hu et al. (2010); ${ }^{9}$ MacDonald and Moore (2007); ${ }^{10}$ Moore and Groszko (1999); ${ }^{11}$ Zhou et al. (2005);

\# macroalgae dominated

Overall, the lagoon seems to comprise highly potent halocarbon sources in the water column for $\mathrm{CH}_{3} \mathrm{Cl}$ and $\mathrm{CH}_{3} \mathrm{Br}$ but not for $\mathrm{CH}_{3} \mathrm{I}$ and $\mathrm{CHBr}_{3}$.

\subsection{Flux pattern from seagrass meadows}

The halocarbon fluxes from seagrass meadows were characterised by a high variability with deposition and emission fluxes occurring at all sampling spots. The same was observed within other studies investigating halocarbon fluxes in coastal environments (e.g. Blei et al., 2010; Manley et al., 2006; Rhew et al., 2000). Halocarbon dynamics in coastal systems where multiple sources and sinks interact are complex, and it should be noted that the fluxes discussed here refer to the entire benthic community constituting the seagrass meadows. Thus, some variability may relate to the activity of distinct source organisms, which may be stimulated by different environmental factors. To gain insights into the common environmental controls for this ecosystem, we discuss the following factors: (i) diurnal variations; (ii) tidal effects; and (iii) seasonal dependence.

(i) Diurnal variations. The correlation analysis with solar radiation resulted in only a weak association with the magnitude of fluxes. However, after grouping by daytime, our data provide some indication for a diurnal pattern (Fig. 2). For $\mathrm{CH}_{3} \mathrm{Cl}$, there was the most obvious relationship between time of day and actual emissions. Highest emissions were observed during day periods with increased sunlight (midday and afternoon). In contrast, deposition fluxes were exclusively recorded during periods of low radiation and at nighttime. The same was also observed for $\mathrm{CH}_{3} \mathrm{Br}$. However, highest mean emissions of this compound seemed to be shifted to- wards the afternoon. $\mathrm{CH}_{3} \mathrm{I}$ was constantly emitted from the seagrass covered spot, revealing a weak diurnal dependence. The emissions did not cease during periods of low irradiance and darkness. Nevertheless, elevated mean emissions were observed in the afternoon. Except for one occasion, $\mathrm{CHBr}_{3}$ was emitted throughout the sampling periods. Mean emissions were higher around midday and afternoon than during the night.

Several studies from salt marshes reported a diurnal trend of halocarbon emissions initiated by irradiance (Dimmer et al., 2001; Rhew et al., 2000, 2002; Drewer et al., 2006). The flux data of halocarbons from the summer campaign with elevated fluxes during midday and afternoon suggest a similar pattern also in seagrass meadows. However, this was more obvious for $\mathrm{CH}_{3} \mathrm{Cl}$ and $\mathrm{CH}_{3} \mathrm{Br}$ than for $\mathrm{CH}_{3} \mathrm{I}$ and $\mathrm{CHBr}_{3}$. The lower production of $\mathrm{CH}_{3} \mathrm{I}$ during the time of highest light intensity cannot fully be explained. Blei et al. (2010) reported that the main environmental association in salt marsh emissions of $\mathrm{CH}_{3} \mathrm{Cl}$ and $\mathrm{CH}_{3} \mathrm{Br}$ was with ambient temperature rather than light. However, during the summer campaign, temperature variations (day/night) were too low to explain the observed emission/deposition pattern of $\mathrm{CH}_{3} \mathrm{Cl}$ and $\mathrm{CH}_{3} \mathrm{Br}$.

It is known that coastal sediments can act as a sink for $\mathrm{CH}_{3} \mathrm{Cl}$ and $\mathrm{CH}_{3} \mathrm{Br}$, mainly due to microbial degradation (Miller et al., 2004; Oremland et al., 1994). This would support our findings of the deposition fluxes during nighttime, where production above the sediment is presumably lower than during daytime (summer campaign). While, in general, the deposition fluxes of $\mathrm{CH}_{3} \mathrm{Cl}$ and $\mathrm{CH}_{3} \mathrm{Br}$ occurred more frequently during 

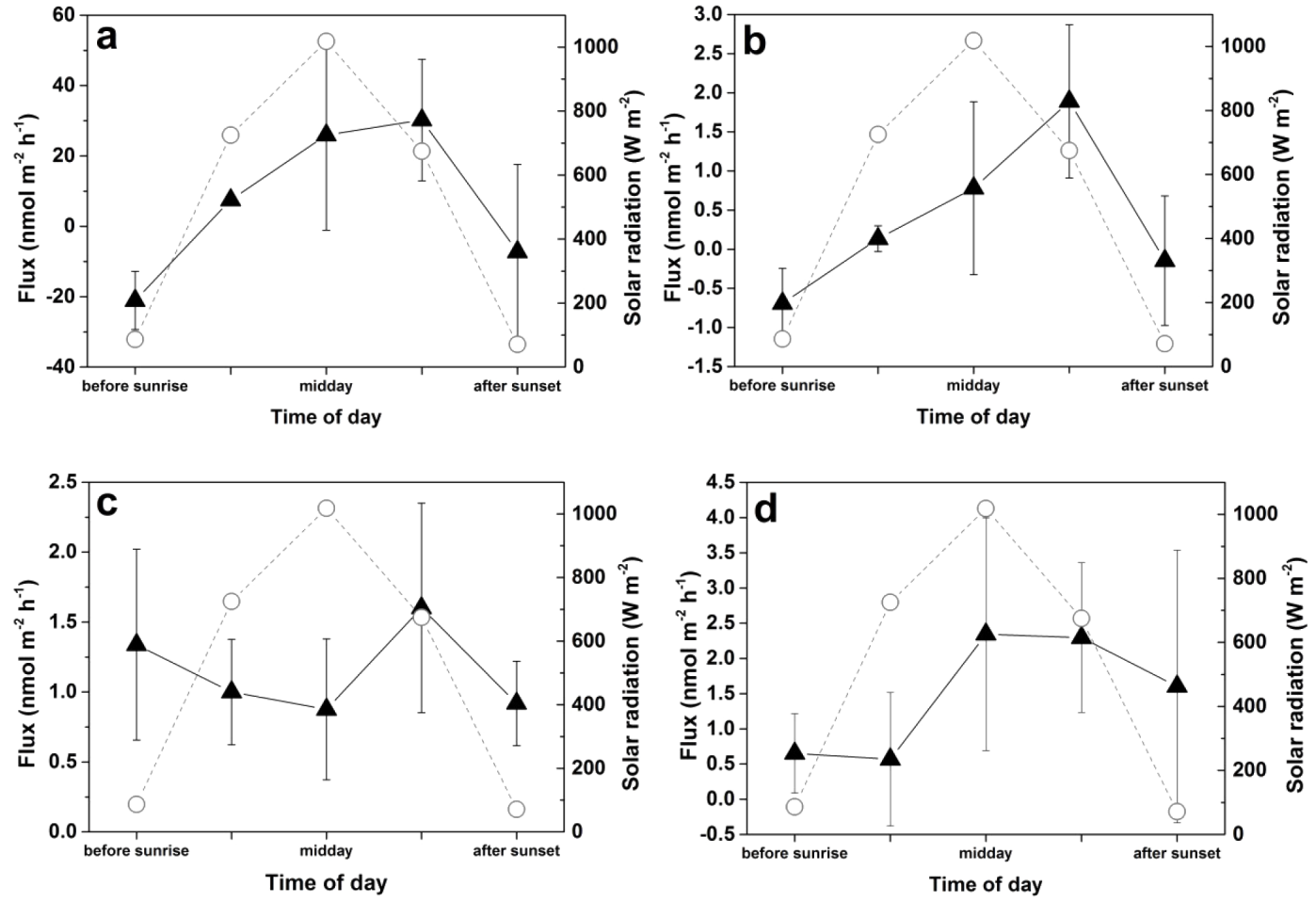

Figure 2. Diurnal variation of mean halocarbon fluxes (triangles) from seagrass meadows during periods of air exposure in summer 2011 (a: $\mathrm{CH}_{3} \mathrm{Cl}$, b: $\mathrm{CH}_{3} \mathrm{Br}$, c: $\mathrm{CH}_{3} \mathrm{I}, \mathbf{d}: \mathrm{CHBr}_{3}$ ). Error bars refer to standard deviations. Circles are solar radiation values. Note that the scales on the $y$ axis are different for each compound.

the spring campaign, they did not exhibit a day-night relationship. Moreover, the dependence of light intensity on the magnitude of emission fluxes of halocarbons seemed to have a minor effect during this period of the year.

(ii) Tidal effects. During the spring campaign, mean fluxes derived from submerged seagrass meadows were elevated by factors of $17\left(\mathrm{CH}_{3} \mathrm{Cl}\right), 5\left(\mathrm{CH}_{3} \mathrm{Br}\right), 3\left(\mathrm{CH}_{3} \mathrm{I}\right)$, and $8\left(\mathrm{CHBr}_{3}\right)$ when compared to the average fluxes during air exposure. This clearly higher production of halocarbons under submerged conditions was quite unexpected, as in general it is believed that the production of trace gases during low tide exceeds that during inundation. For halocarbons, this was suggested for example by Carpenter et al. (1999) and Jones et al. (2009) from atmospheric measurements over intertidal macroalgae beds in Mace Head, Ireland. Nevertheless, in accordance with our results from halocarbon measurements we also observed higher primary productivity by increased $\mathrm{CO}_{2}$ uptake during submerged conditions (Bahlmann et al., 2014). Therefore, the higher productivity may reflect higher enzymatic activity (e.g. methyltransferases) within the organisms of the seagrass community, by which monohalomethanes are presumably formed. Furthermore, the correlation analysis revealed a different behaviour of halocarbons between the two tidal states, with stronger correlations between monohalomethanes during tidal inundation than air exposure. Obviously the change in environmental conditions was accompanied with a shift in the halocarbon production-decomposition pattern of the benthic community and/or different source organisms were stimulated.

An interesting outcome of both campaigns is the observation of strongly elevated halocarbon fluxes during tidal change, from air exposure to submergence and reversely (Table 3). Continuous high-time resolution $\mathrm{CO}_{2}$ and methane flux measurements performed in spring 2012 (Bahlmann et al., 2014) principally support this observation. At the particular moment when the water reached the sampling site, we observed a distinct peak flux of methane and $\mathrm{CO}_{2}$. This may be evidence for processes in the sediments attributable to changes in hydrodynamic pressures, resulting in the release of trace gases trapped in sedimentary pore spaces (Bahlmann et al., 2014). The remarkable deposition flux of $\mathrm{CH}_{3} \mathrm{Cl}$ and $\mathrm{CH}_{3} \mathrm{Br}$ during the maximum water level (Table 3) was accompanied by highest emissions of other trace gases, such as methanethiol and hydrogen sulfide, as discussed by Bahlmann et al. (2014). These compounds are effective nucleophiles, which could have contributed to the 
degradation of halocarbons as described in Barbash and Reinhard (1989). This suggests a significantly different biogeochemistry during this period compared with tide and ebb flow.

Overall, while there is evidence for a tidal control on halocarbon production and decomposition, additional research is needed to further elucidate these phenomena.

(iii) Seasonal dependence. There are considerable differences between the results from the spring and summer campaigns. We observed elevated mixing ratios for all halocarbons in ambient air, as well as higher water concentrations for $\mathrm{CH}_{3} \mathrm{Cl}, \mathrm{CH}_{3} \mathrm{I}$, and $\mathrm{CHBr}_{3}$ compounds in summer (Table 1). This observed signal of general increased halocarbon production in the lagoon during summer might be attenuated by enhanced degradation in the water phase and sediments at higher temperatures. Nevertheless, given the calculated sea-air flux there is only little evidence for a pronounced seasonal relationship in halocarbon volatilisation to the atmosphere from the lagoon water. While the fluxes of $\mathrm{CH}_{3} \mathrm{Cl}$ appeared to be enhanced in summer, those of $\mathrm{CH}_{3} \mathrm{Br}$ and $\mathrm{CH}_{3} \mathrm{I}$ seemed to be quite similar between spring and summer. $\mathrm{CHBr}_{3}$ emissions were actually higher in spring than in summer due to higher water concentrations. Comparing the data obtained from air-exposed sites during the two campaigns, the fluxes in summer were strongly enhanced by factors of $16\left(\mathrm{CH}_{3} \mathrm{Cl}\right.$ and $\left.\mathrm{CH}_{3} \mathrm{Br}\right)$, $2\left(\mathrm{CH}_{3} \mathrm{I}\right)$, and $5\left(\mathrm{CHBr}_{3}\right)$. Moreover, the halocarbon fluxes showed a distinct diurnal cycle during summer but not during spring. The differences of ambient conditions between the campaigns with lower air temperatures and lower solar radiation in spring may have contributed to the differences in the emission patterns of halocarbons. That these environmental conditions can substantially influence the magnitude of fluxes was reported from other ecosystems such as salt marshes (Blei et al., 2010; Manley et al., 2006). However, further studies covering the entire seasoning are necessary to fully unravel the annual halocarbon emissions from seagrass meadows.

\subsection{Halocarbons sources in the lagoon: an isotopic perspective}

The results from the atmospheric sampling of Praia de Faro air (upwind) and lagoon air revealed differences regarding the mixing ratios and $\delta^{13} \mathrm{C}$ values of $\mathrm{CH}_{3} \mathrm{Cl}$ and $\mathrm{CH}_{3} \mathrm{Br}$ (Tables 1 and 4). We observed elevated concentrations in the lagoon for both compounds, whereby the higher concentrations were accompanied with shifts towards isotopically light $\mathrm{CH}_{3} \mathrm{Cl}$ but heavy $\mathrm{CH}_{3} \mathrm{Br}$. Sources other than the studied seagrass meadows, for example the abundant salt marshes, may have contributed substantially to the elevated mixing ra- tios. Assuming atmospheric stable conditions with negligible sinks in the atmosphere, the difference of air mixing ratios and $\delta^{13} \mathrm{C}$ values between upwind air and lagoon air should reflect the isotopic source signature within the lagoon. Therefore, as a first approach, an isotope mass balance was used by integrating mean data from both sampling sites (Tables 1 and 4). The resulting source signatures within the lagoon are $-49 \%$ of $\mathrm{CH}_{3} \mathrm{Cl}$ and $-16 \%$ ofor $\mathrm{CH}_{3} \mathrm{Br}$.

Isotopic source signatures of $\mathrm{CH}_{3} \mathrm{Cl}$ from seagrass meadows during chamber incubations (air exposure) in the Ria Formosa were $-51 \pm 6 \%$ (summer) and $-56 \pm 2 \%$ o (spring). During the summer campaign, $\mathrm{CH}_{3} \mathrm{Cl}$ emissions from the salt marsh plant Spartina maritima were determined with $\delta^{13} \mathrm{C}$ values of -66 and $-72 \%$. These values are in good agreement with those of Bill et al. (2002) from a Californian salt marsh ( -69 to $-71 \%$, daytime values). Unfortunately, we do not have isotopic data for the inundated periods from seagrass meadows, but the $\delta^{13} \mathrm{C}$ values of $\mathrm{CH}_{3} \mathrm{Cl}$ in the water phase $(-42 \pm 2 \%$ o come close to those measured in the atmosphere. An abiotic production mechanism has been reported for $\mathrm{CH}_{3} \mathrm{Cl}$ from senescent plant material (Hamilton et al., 2003). While we cannot generally exclude additional $\mathrm{CH}_{3} \mathrm{Cl}$ generation via this pathway, the isotopic data obtained in the Ria Formosa do not mirror strongly ${ }^{13} \mathrm{C}$ depleted values ( $\delta^{13} \mathrm{C}$ of $-135 \pm 12 \%$, Keppler et al., 2004) as expected for compounds from this production mechanism. Overall, this rather indicates a stronger imprint of the seagrass meadows and/or water column on the atmospheric $\mathrm{CH}_{3} \mathrm{Cl}$ than from salt marshes or abiotic processes.

With $\delta^{13} \mathrm{C}$ values of $-42 \pm 17 \%$, the source signature of $\mathrm{CH}_{3} \mathrm{Br}$ from seagrass meadows tend to be more depleted in ${ }^{13} \mathrm{C}$ compared with the calculated source signature from the atmospheric samples. It should be noted that the $\delta^{13} \mathrm{C}$ values for this compound were more depleted in ${ }^{13} \mathrm{C}$ during periods of increased emission $(-55 \%$ ) than during low emission $(-28 \% o)$. This shift can most likely be explained by degradation processes in the sediments, which occurred simultaneously. This corroborates our observations from northern Germany with subsequent recalculation of a sedimentary sink function from accompanying sediment measurements (Weinberg et al., 2013). Reported source signatures of $\mathrm{CH}_{3} \mathrm{Br}$ from salt marshes range from -59 to $-65 \%$ (day time values, Bill et al., 2002). Our own measurements in the Ria Formosa indicate similar $\delta^{13} \mathrm{C}$ values $(-65 \%$ ) or even more depleted ones (unpublished data). In any case, neither source signatures from seagrass meadows nor salt marshes seem to match the overall source signature estimated from the atmospheric samples. Therefore, it is most likely that the atmospheric $\mathrm{CH}_{3} \mathrm{Br}$ is strongly influenced by $\mathrm{CH}_{3} \mathrm{Br}$ emissions from the surface waters $\left(\delta^{13} \mathrm{C}\right.$ values in water phase (summer): $-23 \pm 3 \%$ ). Even during periods of low tide the water remains in the deep channels, which may be sufficient to have an impact on the local atmosphere. Thus, despite the sources in the lagoon presumably producing isotopically light $\mathrm{CH}_{3} \mathrm{Br}, \delta^{13} \mathrm{C}$ values in the atmosphere strongly reflect decomposed $\mathrm{CH}_{3} \mathrm{Br}$, whose 
residual fraction is actually enriched in ${ }^{13} \mathrm{C}$. Accordingly, aqueous $\mathrm{CH}_{3} \mathrm{Br}$ appears to become rapidly degraded by biotic/abiotic processes such as hydrolysis, transhalogenation, and microbial degradation with strong isotopic fractionation (King and Saltzman, 1997; Miller et al., 2004). These decomposition mechanisms are temperature dependent, with increasing destruction as seawater temperature rises (King and Saltzman, 1997). This is most likely the reason why the $\delta^{13} \mathrm{C}$ values in the lagoon waters in summer are more enriched in ${ }^{13} \mathrm{C}$, compared with those from the spring campaign.

To the best of our knowledge, this is the first report of $\delta^{13} \mathrm{C}$ values of $\mathrm{CH}_{3} \mathrm{I}$ in the water phase. As shown by the water samples from the transect cruise, the sources in the lagoon may produce isotopic light $\mathrm{CH}_{3} \mathrm{I}$. Given this, $\mathrm{CH}_{3} \mathrm{I}$ seems, to some extent, to follow the $\delta^{13} \mathrm{C}$ values of $\mathrm{CH}_{3} \mathrm{Cl}$. These sources may be biotic, by e.g. phytoplankton, seagrass meadows, or bacteria. On the other hand, Moore and Zafirou (1994) reported a photochemical source for $\mathrm{CH}_{3} \mathrm{I}$ by radical recombination of iodine with seawater dissolved organic matter. Due to the lack of isotopic source signatures and fractionation factors for production (and consumption), it is difficult to draw conclusions from the data.

The $\delta^{13} \mathrm{C}$ values of $\mathrm{CHBr}_{3}$ were more depleted in ${ }^{13} \mathrm{C}$ from the lagoon inlet towards the parts deeper inside. This suggests a different combination of sources in water masses coming from the Atlantic. Moreover, this potential variation of source contribution can be further assumed by the certain change between summer and spring where e.g. macroalgae are more abundant in the latter period (Anibal et al., 2007). Already reported source signatures of phytoplankton, macroalgae, and seagrass meadows cover the range of -10 to $-23 \%$ (Auer et al., 2006; Weinberg et al., 2013), thus demonstrating differences in their isotopic fingerprint. We cannot exclude that degradation might also have an effect on the $\delta^{13} \mathrm{C}$ values determined in lagoon waters. As for $\mathrm{CH}_{3} \mathrm{I}$, there is still need for further research on the $\mathrm{CHBr}_{3}$ cycling utilising stable carbon isotopes.

\subsection{Magnitude of fluxes and comparison to other coastal measurements and first estimate of global source strength}

The area-based fluxes of $\mathrm{CH}_{3} \mathrm{Cl}, \mathrm{CH}_{3} \mathrm{Br}$, and $\mathrm{CH}_{3} \mathrm{I}$ from seagrass meadows in comparison to emission data of other coastal sources are presented in Fig. 3. In comparison to the emissions from a temperate seagrass meadow in late summer in northern Germany (Weinberg et al., 2013), fluxes were elevated in the subtropical lagoon in summer during air exposure. This was more pronounced for $\mathrm{CH}_{3} \mathrm{Br}$ (factor 33) than for $\mathrm{CH}_{3} \mathrm{Cl}$ (factor 2), $\mathrm{CH}_{3} \mathrm{I}$ (factor 2), and $\mathrm{CHBr}_{3}$ (factor 5). In contrast, fluxes from air-exposed seagrass meadows recorded during spring are comparable to those determined in northern Germany. Thus, the difference between fluxes from temperate and subtropical regions is less pronounced than re- ported for salt marshes with emissions from subtropical regions, exceeding those from temperate regions by up to two orders of magnitude for $\mathrm{CH}_{3} \mathrm{Cl}$ and $\mathrm{CH}_{3} \mathrm{Br}$ (Blei et al. 2010; Cox et al., 2004; Dimmer et al., 2001; Drewer et al., 2006; Manley et al., 2006; Rhew and Mazéas, 2010; Rhew et al., 2000, 2014; Valtanen et al., 2009). Beside this regional (climatic) difference, several authors attributed this to a highly species dependent emission potential.

Average emissions of $\mathrm{CH}_{3} \mathrm{Cl}$ from the air-exposed seagrass meadows in summer are in the same range than those determined in temperate salt marshes (Blei et al. 2010; Cox et al., 2004; Dimmer et al., 2001; Drewer et al., 2006; Valtanen et al., 2009). In contrast, subtropical counterparts of these macrophytes are distinctively stronger emitters of this compound by at least one order of magnitude (Manley et al., 2006; Rhew and Mazéas, 2010; Rhew et al., 2000, 2014). Greenhouse grown mangroves produce significantly more $\mathrm{CH}_{3} \mathrm{Cl}$ than seagrass meadows, revealing a higher emission potential for these plant species on a per area basis (Manley et al., 2007).

Fluxes of $\mathrm{CH}_{3} \mathrm{Br}$ from subtropical seagrass meadows during air exposure exceed those of temperate macroalgae from Mace Head, Ireland (Carpenter et al., 2000) and temperate salt marshes (Blei et al. 2010; Cox et al., 2004; Dimmer et al., 2001; Drewer et al., 2006; Valtanen et al., 2009). However, the $\mathrm{CH}_{3} \mathrm{Br}$ fluxes from seagrass meadows are distinctively lower than those of subtropical salt marsh plants (Manley et al., 2006; Rhew and Mazéas, 2010; Rhew et al., 2000). Mangroves seem to have a similar emission potential as seagrass meadows (Manley et al., 2007).

For $\mathrm{CH}_{3} \mathrm{I}$, seagrass meadows are a minor source in comparison to the high release of macroalgae in subtropical areas (Leedham et al., 2013). Except for salt marshes from Tasmania (Cox et al., 2004), plant-related communities such as mangroves (Manley et al., 2007) and salt marshes (Dimmer et al., 2001) are more pronounced emission sources of this compound. The same holds true for $\mathrm{CHBr}_{3}$, where macroalgae communities from temperate and subtropical/tropical regions dominate the emissions of polyhalomethanes on a per area basis (e.g. Carpenter et al., 2000; Gschwend et al., 1985; Leedham et al., 2013).

Many uncertainties arise from a limited number of emission data to estimate the global relevance of seagrass meadows. There may be high variation in space and time, high heterogeneity of seagrass meadows, species dependent emission potential, and errors regarding the global seagrass abundance. Therefore, the scale-up of our data gives only a first rough approximation; it was undertaken as follows. Since we did not measure a full annual cycle, we assumed that seagrass measurements during the summer campaign represent emissions from the reproductive season (May-September). The remaining period of the year (October-April) was calculated with emission data from the spring campaign. The emission data were weighted to tidal states using 8 and $16 \mathrm{~h}$ per day as durations when seagrass meadows are air-exposed 

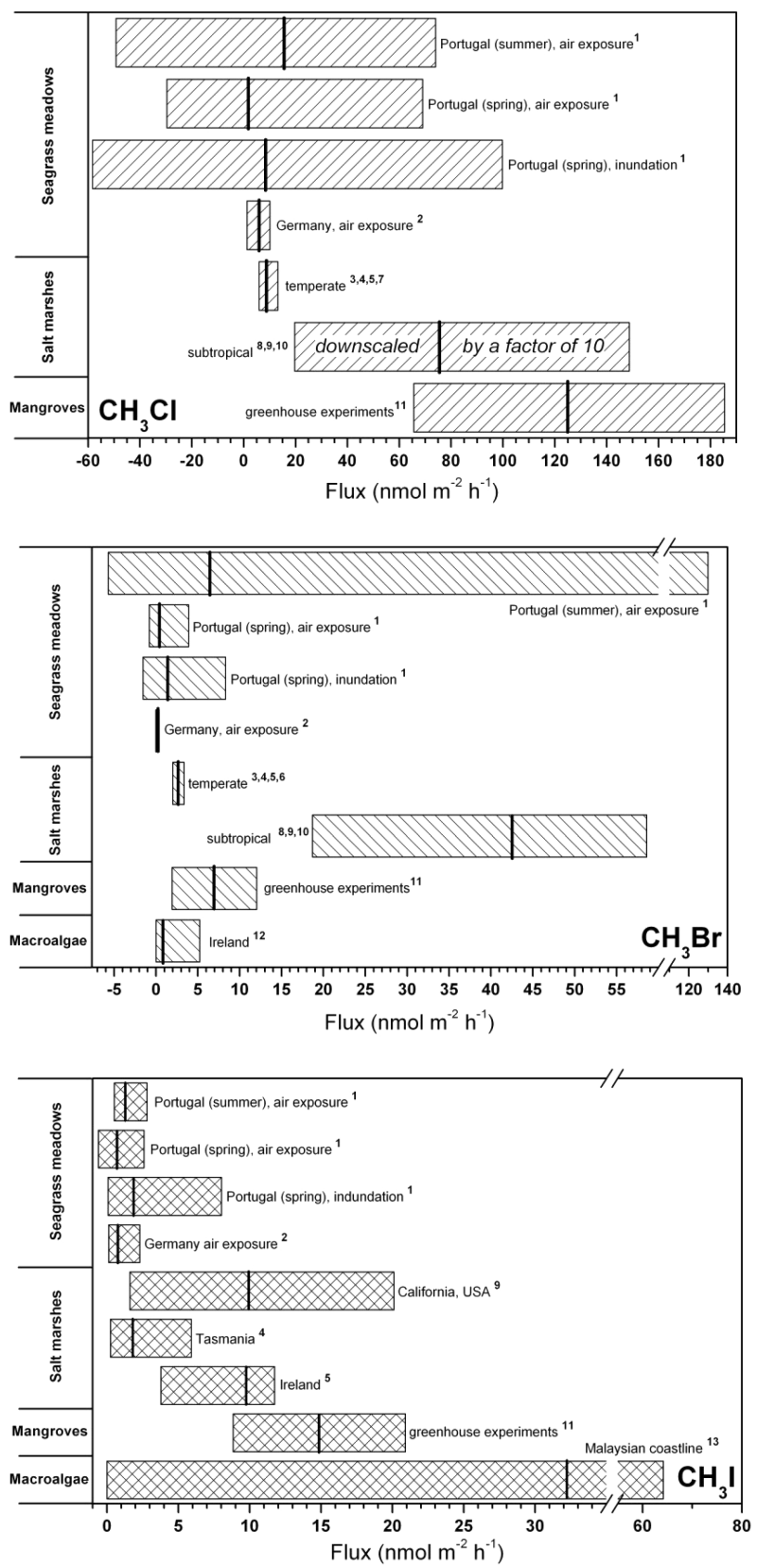

Figure 3. Compilation of mean emissions (bold black vertical lines) and ranges from different sources in coastal environments for $\mathrm{CH}_{3} \mathrm{Cl}$ (upper panel), $\mathrm{CH}_{3} \mathrm{Br}$ (middle panel) and $\mathrm{CH}_{3} \mathrm{I}$ (lower panel). Note the different scales. Published data adopted from: ${ }^{1}$ this study; ${ }^{2}$ Weinberg et al. (2013); ${ }^{3}$ Blei et al. (2010); ${ }^{4}$ Cox et al. (2004); ${ }^{5}$ Dimmer et al. (2001); ${ }^{6}$ Drewer et al. (2006); ${ }^{7}$ Valtanen et al. (2009); ${ }^{8}$ Rhew and Mazéas (2010); ${ }^{9}$ Manley et al., (2006); ${ }^{10}$ Rhew et al. (2000); ${ }^{11}$ Manley et al. (2007); ${ }^{12}$ Carpenter et al. (2000); ${ }^{13}$ Leedham et al. (2013). Note that the data of $\mathrm{CH}_{3} \mathrm{Cl}$ from subtropical salt marshes are downscaled by a factor of 10 for visualisation reasons. Where multiple references were used, the individual study means were averaged and presented along with the resulting ranges. Thus, ranges of halocarbon fluxes in each single study are not covered. Studies reporting a strong species dependency in magnitude of fluxes were averaged over all species groups for simplicity. Macroalgae emissions given in $\mathrm{g}$ fresh weight per hour were converted by using the species' fresh weights and spatial coverage in the coastal belt in Mace Head, Ireland for $\mathrm{CH}_{3} \mathrm{Br}$ (Carpenter et al., 2000) and the Malaysian coastline for $\mathrm{CH}_{3} \mathrm{I}(\mathrm{Leedham}$ et al., 2013), respectively.

or submerged, respectively. Due to the lack of flood tide emission data in summer, we used those derived from the sea-air exchange. The resulting average annual emissions from seagrass meadows of $150 \mu \mathrm{mol} \mathrm{m}^{-2} \mathrm{yr}^{-1}\left(\mathrm{CH}_{3} \mathrm{Cl}\right)$, $18 \mu \mathrm{mol} \mathrm{m}^{-2} \mathrm{yr}^{-1}\left(\mathrm{CH}_{3} \mathrm{Br}\right), 14 \mu \mathrm{mol} \mathrm{m}^{-2} \mathrm{yr}^{-1}\left(\mathrm{CH}_{3} \mathrm{I}\right)$, and $25 \mu \mathrm{mol} \mathrm{m}^{-2} \mathrm{yr}^{-1}\left(\mathrm{CHBr}_{3}\right)$ were scaled-up with the cur- 
rent estimates of a global seagrass area, ranging from $0.3 \times 10^{12} \mathrm{~m}^{2}$ (Duarte et al., 2005) to $0.6 \times 10^{12} \mathrm{~m}^{2}$ (CharpyRoubaud and Sournia, 1990).

The tentative estimate yields annual emissions of 2.3$4.5 \mathrm{Gg} \mathrm{yr}^{-1}$ for $\mathrm{CH}_{3} \mathrm{Cl}, 0.5-1.0 \mathrm{Gg} \mathrm{yr}^{-1}$ for $\mathrm{CH}_{3} \mathrm{Br}$, 0.6$1.2 \mathrm{Gg} \mathrm{yr}^{-1}$ for $\mathrm{CH}_{3} \mathrm{I}$, and $1.9-3.7 \mathrm{Gg} \mathrm{yr}^{-1}$ for $\mathrm{CHBr}_{3}$. Based on the recent global budget calculations (Xiao et al., 2010; Montzka and Reimann, 2011), these ranges are equivalent to 0.06-0.11 and 0.45-0.89\%, for $\mathrm{CH}_{3} \mathrm{Cl}$ and $\mathrm{CH}_{3} \mathrm{Br}$, respectively. Seagrass meadows would therefore cover a portion of $1.4-2.8 \%$ of the missing sources for $\mathrm{CH}_{3} \mathrm{Br}$ reported in the most recent World Meteorological Organization (WMO) report (36.1 $\mathrm{Gg} \mathrm{yr}^{-1}$; Montzka and Reimann, 2011). Given the emissions from oceanic sources (e.g. Butler et al., 2007; Quack and Wallace, 2003, and references therein), $\mathrm{CH}_{3} \mathrm{I}$ and $\mathrm{CHBr}_{3}$ emissions from seagrass meadows are rather insignificant on a global scale.

\section{Conclusions}

Our data are the first to report detailed halocarbon fluxes from seagrass meadows. The fluxes of halocarbons were highly variable with increased fluxes when the seagrass meadows were submerged, and distinct emission peaks when lagoon waters were just arriving or leaving the sampling site. For $\mathrm{CH}_{3} \mathrm{Cl}$ and $\mathrm{CH}_{3} \mathrm{Br}$, we observed a diurnal dependence on the fluxes with increased emissions during midday/afternoon and deposition fluxes during periods of low radiation. Generally, diurnal variations (during air exposure), atmospheric mixing ratios, and emission rates of halocarbons were smaller in spring than in summer, suggesting a seasonal dependence. Our results indicate that on a global scale, seagrass meadows are a minor source of halocarbons, but that they will have an imprint on the local and regional budgets, particularly on subtropical coastlines, where seagrass meadows belong to the most abundant ecosystems.

Our stable carbon isotope results suggest that $\mathrm{CH}_{3} \mathrm{Cl}$ originates predominantly from the water column and/or seagrass meadows, rather than from adjacent salt marshes or abiotic formation processes. Atmospheric and aqueous $\mathrm{CH}_{3} \mathrm{Br}$ in the lagoon was substantially enriched in ${ }^{13} \mathrm{C}$ pointing towards degradation processes and re-emission into the atmosphere.

Future studies should focus on halocarbon emissions from seagrass-based systems from different regions in order to refine the global relevance. Since the magnitudes of fluxes are often species dependent, budget calculations would benefit from a more detailed investigation of fluxes from different seagrass species. More work is also required to identify other elements of these ecosystems, such as the sediments, which are capable of acting as both a sink and a source of halocarbons.

The Supplement related to this article is available online at doi:10.5194/bg-12-1697-2015-supplement.
Acknowledgements. The authors thank the German Federal Ministry of Education and Research (BMBF) for funding (grants 03F0611E and 03F0662E). The stay at the Ramalhete research station in Faro, Portugal was co-funded by ASSEMBLE EU FP7 research infrastructure project. Rui Santos, João Reis, and Bruno Fragoso (CCMAR, Universidade do Algarve) are greatly acknowledged for their extensive support during sampling site selection and sampling. Our technical staff members Sabine Beckmann and Ralf Lendt are thanked for their valuable help. We express gratitude to three anonymous reviewers and especially the Associate Editor Jens-Arne Subke for their comments and suggestions, which considerably improved the quality of the manuscript.

Edited by: J.-A. Subke

\section{References}

Amachi, S., Kamagata, Y., Kanagawa, T., and Muramatsu, Y.: Bacteria mediate methylation of iodine in marine and terrestrial environments, Appl. Environ. Microb., 67, 2718-2722, 2001.

Anibal, J., Rocha, C., and Sprung, M.: Mudflat surface morphology as a structuring agent of algae and associated macroepifauna communities: A case study in the Ria Formosa, J. Sea Res., 57, 36-46, 2007.

Auer, N. R., Manzke, B. U., and Schulz-Bull, D. E.: Development of a purge and trap continuous flow system for the stable carbon isotope analysis of volatile halogenated organic compounds in water, J. Chromatogr. A, 1131, 24-36, 2006.

Bahlmann, E., Weinberg, I., Seifert, R., Tubbesing, C., and Michaelis, W.: A high volume sampling system for isotope determination of volatile halocarbons and hydrocarbons, Atmos. Meas. Tech., 4, 2073-2086, doi:10.5194/amt-4-2073-2011, 2011.

Bahlmann, E., Weinberg, I., Lavric(, J. V., Eckhard, T., Michaelis, W., Santos, R., and Seifert, R.: Tidal controls on trace gas dynamics in a seagrass meadow of the Ria Formosa lagoon (southern Portugal), Biogeosciences Discuss., 11, 10571-10603, doi:10.5194/bgd-11-10571-2014, 2014.

Baker, J. M., Reeves, C. E., Nightingale, P. D., Penkett, S. A., Gibb, S. W., and Hatton, A. D.: Biological production of methyl bromide in the coastal waters of the North Sea and open ocean of the northeast Atlantic, Mar. Chem., 64, 267-285, 1999.

Barbash, J. E. and Reinhard, M.: Reactivity of sulfur nucleophiles toward halogenated organic compounds in natural waters, in: Biogenic Sulfur in the Environment, edited by: Saltzman, E. and Cooper, W. J., American Chemical Society, Washington DC, 101-137, 1989.

Bell, N., Hsu, L., Jacob, D. J., Schultz, M. G., Blake, D. R., Butler, J. H., King, D. B., Lobert, J. M., and Maier-Reimer, E.: Methyl iodide: Atmospheric budget and use as a tracer of marine convection in global models, J. Geophys. Res.-Atmos., 107, 4340, doi:10.1029/2001jd001151, 2002.

Bill, M., Rhew, R. C., Weiss, R. F., and Goldstein, A. H.: Carbon isotope ratios of methyl bromide and methyl chloride emitted from a coastal salt marsh, Geophys. Res. Lett., 29, 4-1-4-4, doi:104510.1029/2001g1012946, 2002. 
Blei, E., Heal, M. R., and Heal, K. V.: Long-term $\mathrm{CH} 3 \mathrm{Br}$ and $\mathrm{CH}_{3} \mathrm{Cl}$ flux measurements in temperate salt marshes, Biogeosciences, 7 , 3657-3668, doi:10.5194/bg-7-3657-2010, 2010.

Borges, A. V., Vanderborght, J. P., Schiettecatte, L. S., Gazeau, F., Ferron-Smith, S., Delille, B., and Frankignoulle, M.: Variability of the gas transfer velocity of $\mathrm{CO}_{2}$ in a macrotidal estuary (the Scheldt), Estuaries, 27, 593-603, 2004.

Bravo-Linares, C. M. and Mudge, S. M.: Temporal trends and identification of the sources of volatile organic compounds in coastal seawater, J. Environ. Monitor, 11, 628-641, 2009.

Brito, A., Newton, A., Tett, P., and Fernandes, T. F.: Sediment and water nutrients and microalgae in a coastal shallow lagoon, Ria Formosa (Portugal): Implications for the Water Framework Directive, J. Environ. Monitor, 12, 318-328, 2010.

Brito, A. C., Quental, T., Coutinho, T. P., Branco, M. A. C., Falcao, M., Newton, A., Icely, J., and Moita, T.: Phytoplankton dynamics in southern Portuguese coastal lagoons during a discontinuous period of 40 years: an overview, Estuar. Coast. Shelf S., 110, 147-156, 2012.

Butler, J. H., King, D. B., Lobert, J. M., Montzka, S. A., YvonLewis, S. A., Hall, B. D., Warwick, N. J., Mondeel, D. J., Aydin, M., and Elkins, J. W.: Oceanic distributions and emissions of short-lived halocarbons, Global Biogeochem. Cy., 21, GB1023, doi:10.1029/2006gb002732, 2007.

Cabaço, S., Machás, R., and Santos, R.: Individual and population plasticity of the seagrass Zostera noltii along a vertical intertidal gradient, Estuar. Coast. Shelf S., 82, 301-308, 2009.

Cabaço, S., Santos, R., and Sprung, M.: Population dynamics and production of the seagrass Zostera noltii in colonizing versus established meadows, Mar. Ecol., 33, 280-289, 2012.

Carpenter, L. J., Sturges, W. T., Penkett, S. A., Liss, P. S., Alicke, B., Hebestreit, K., and Platt, U.: Short-lived alkyl iodides and bromides at Mace Head, Ireland: Links to biogenic sources and halogen oxide production, J. Geophys. Res.-Atmos., 104, 16791689, 1999.

Carpenter, L. J., Malin, G., Liss, P. S., and Küpper, F. C.: Novel biogenic iodine-containing trihalomethanes and other short-lived halocarbons in the coastal east Atlantic, Global Biogeochem. Cy., 14, 1191-1204, 2000.

Carpenter, L. J., Jones, C. E., Dunk, R. M., Hornsby, K. E., and Woeltjen, J.: Air-sea fluxes of biogenic bromine from the tropical and North Atlantic Ocean, Atmos. Chem. Phys., 9, 1805-1816, doi:1805-1816,10.5194/acp-9-1805-2009, 2009.

Charpy-Roubaud, C. and Sournia, A.: The comparative estimation of phytoplanktonic microphytobenthic and macrophytobenthic primary production in the oceans, Mar. Microb. Food Webs, 4, 31-58, 1990.

Cox, M. L., Fraser, P. J., Sturrock, G. A., Siems, S. T., and Porter, L. W.: Terrestrial sources and sinks of halomethanes near Cape Grim, Tasmania, Atmos. Environ., 38, 3839-3852, 2004.

DeBruyn, W. J. and Saltzman, E. S.: The solubility of methyl bromide in pure water, 35 parts per thousand sodium chloride and seawater, Mar. Chem., 56, 51-57, 1997.

Dimmer, C. H., Simmonds, P. G., Nickless, G., and Bassford, M. R.: Biogenic fluxes of halomethanes from Irish peatland ecosystems, Atmos. Environ., 35, 321-330, 2001.

Drewer, J., Heal, M. R., Heal, K. V., and Smith, K. A.: Temporal and spatial variation in methyl bromide flux from a salt marsh, Geophys. Res. Lett., 33, L16808, doi:10.1029/2006g1026814, 2006.
Duarte, C. M., Middelburg, J. J., and Caraco, N.: Major role of marine vegetation on the oceanic carbon cycle, Biogeosciences, 2 , 1-8, doi:10.5194/bg-2-1-2005, 2005.

Duarte, P., Azevedo, B., Guerreiro, M., Ribeiro, C., Bandeira, R., Pereira, A., Falcao, M., Serpa, D., and Reia, J.: Biogeochemical modelling of Ria Formosa (South Portugal), Hydrobiologia, 611, 115-132, 2008.

Durham, L.: A Kinematic Study of the Ancão Basin in the Ria Formosa Lagoon, Algarve, MSc thesis, School of Ocean Sciences, University of Wales, Bangor, 2000.

Elliott, S. and Rowland, F. S.: Nucleophilic-substitution rates and solubilities for methyl halides in seawater, Geophys. Res. Lett., 20, 1043-1046, 1993.

Gschwend, P. M., Macfarlane, J. K., and Newman, K. A.: Volatile Halogenated Organic Compounds Released to Seawater from Temperate Marine Macroalgae, Science, 227, 1033-1035, 1985.

Guimarães, M. H. M. E., Cunha, A. H., Nzinga, R. L., and Marques, J. F.: The distribution of seagrass (Zostera noltii) in the Ria Formosa lagoon system and the implications of clam farming on its conservation, J. Nat. Conservat., 20, 30-40, 2012.

Hamilton, J. T. G., McRoberts, W. C., Keppler, F., Kalin, R. M., and Harper, D. B.: Chloride methylation by plant pectin: An efficient environmentally significant process, Science, 301, 206209, 2003.

Hu, L., Yvon-Lewis, S. A., Liu, Y., Salisbury, J. E., and O’Hern, J. E.: Coastal emissions of methyl bromide and methyl chloride along the eastern Gulf of Mexico and the east coast of the United States, Global Biogeochem. Cy., 24, GB1007, doi:10.1029/2009gb003514, 2010.

Jones, C. E., Hornsby, K. E., Dunk, R. M., Leigh, R. J., and Carpenter, L. J.: Coastal measurements of short-lived reactive iodocarbons and bromocarbons at Roscoff, Brittany during the RHaMBLe campaign, Atmos. Chem. Phys., 9, 8757-8769, doi:10.5194/acp-9-8757-2009, 2009.

Keppler, F., Kalin, R. M., Harper, D. B., McRoberts, W. C., and Hamilton, J. T. G.: Carbon isotope anomaly in the major plant $\mathrm{C} 1$ pool and its global biogeochemical implications, Biogeosciences, 1, 123-131, doi:10.5194/bg-1-123-2004, 2004.

Keppler, F., Harper, D. B., Rockmann, T., Moore, R. M., and Hamilton, J. T. G.: New insight into the atmospheric chloromethane budget gained using stable carbon isotope ratios, Atmos. Chem. Phys., 5, 2403-2411, doi:10.5194/acp-5-2403-2005, 2005.

King, D. B. and Saltzman, E. S.: Removal of methyl bromide in coastal seawater: Chemical and biological rates, J. Geophys. Res.-Oceans, 102, 18715-18721, 1997.

Leedham, E. C., Hughes, C., Keng, F. S. L., Phang, S. M., Malin, G., and Sturges, W. T.: Emission of atmospherically significant halocarbons by naturally occurring and farmed tropical macroalgae, Biogeosciences, 10, 3615-3633, doi:10.5194/bg-10-3615-2013, 2013.

MacDonald, S. and Moore, R. M.: Seasonal and spatial variations in methyl chloride in NW Atlantic waters, J. Geophys. Res.Oceans, 112, C05028, doi:10.1029/2006jc003812, 2007.

Manley, S. L., Wang, N.-Y., Walser, M. L., and Cicerone, R. J.: Coastal salt marshes as global methyl halide sources from determinations of intrinsic production by marsh plants, Global Biogeochem. Cy., 20, GB3015, doi:10.1029/2005gb002578, 2006.

Manley, S. L., Wang, N.-Y., Walser, M. L., and Cicerone, R. J.: Methyl halide emissions from greenhouse-grown mangroves, 
Geophys. Res. Lett., 34, L01806, doi:10.1029/2006gl027777, 2007.

Miller, L. G., Warner, K. L., Baesman, S. M., Oremland, R. S., McDonald, I. R., Radajewski, S., and Murrell, J. C.: Degradation of methyl bromide and methyl chloride in soil microcosms: Use of stable $\mathrm{C}$ isotope fractionation and stable isotope probing to identify reactions and the responsible microorganisms, Geochim. Cosmochim. Ac., 68, 3271-3283, doi:10.1016/j.gca.2003.11.028, 2004.

Montzka, S. A. and Reimann, S.: Ozone-depleting substances and related chemicals, in: Scientific Assessment of Ozone Depletion: 2010, Global Ozone Research and Monitoring Project - Report No. 52, Geneva, Switzerland, 2011.

Moore, R. M.: The solubility of a suite of low molecular weight organochlorine compounds in seawater and implications for estimating the marine source of methyl chloride to the atmosphere, Chemos. Global Change Sci., 2, 95-99,2000.

Moore, R. M. and Groszko, W.: Methyl iodide distribution in the ocean and fluxes to the atmosphere, J. Geophys. Res.-Oceans, 104, 11163-11171, 1999.

Moore, R. M. and Zafiriou, O. C.: Photochemical production of methyl iodide in seawater, J. Geophys. Res.-Atmos., 99, 1641516420, 1994.

Moore, R. M., Geen, C. E., and Tait, V. K.: Determination of Henry's Law constants for a suite of naturally occurring halogenated methanes in seawater, Chemosphere, 30, 1183-1191, 1995.

Moore, R. M., Webb, M., Tokarczyk, R., and Wever, R.: Bromoperoxidase and iodoperoxidase enzymes and production of halogenated methanes in marine diatom cultures, J. Geophys. Res.Oceans, 101, 20899-20908, 1996.

Nightingale, P. D., Malin, G., Law, C. S., Watson, A. J., Liss, P. S., Liddicoat, M. I., Boutin, J., and Upstill-Goddard, R. C.: In situ evaluation of air-sea gas exchange parameterizations using novel conservative and volatile tracers, Global Biogeochem. Cy., 14, 373-387, 2000.

Oremland, R. S., Miller, L. G., and Strohmaier, F. E.: Degradation of Methyl Bromide in Anaerobic Sediments, Environ. Sci. Technol., 28, 514-520, 1994.

Quack, B. and Wallace, D. W. R.: Air-sea flux of bromoform: Controls, rates, and implications, Global Biogeochem. Cy., 17, 1023, doi:10.1029/2002gb001890, 2003

Raymond, P. A. and Cole, J. J.: Gas exchange in rivers and estuaries: Choosing a gas transfer velocity, Estuaries, 24, 312-317, 2001.

Rhew, R. and Mazeas, O.: Gross production exceeds gross consumption of methyl halides in northern California salt marshes, Geophys. Res. Lett., 37, L18813, doi:10.1029/2010g1044341, 2010

Rhew, R. C., Miller, B. R., and Weiss, R. F.: Natural methyl bromide and methyl chloride emissions from coastal salt marshes, Nature, 403, 292-295, 2000.

Rhew, R. C., Miller, B. R., Bill, M., Goldstein, A. H., and Weiss, R. F.: Environmental and biological controls on methyl halide emissions from southern California coastal salt marshes, Biogeochemistry, 60, 141-161, 2002.

Rhew, R. C., Whelan, M. E., and Min D. H.: Large methyl halide emissions from south Texas salt marshes, Biogeosciences Discuss., 11, 9451-9470, doi:10.5194/bgd-11-9451-2014, 2014.
Saito, T. and Yokouchi, Y.: Stable carbon isotope ratio of methyl chloride emitted from glasshouse-grown tropical plants and its implication for the global methyl chloride budget, Geophys. Res. Lett., 35, L08807, doi:10.1029/2007gl032736, 2008.

Saiz-Lopez, A. and von Glasow, R.: Reactive halogen chemistry in the troposphere, Chem. Soc. Rev., 41, 6448-6472, 2012.

Santos, R., Silva, J., Alexandre, A., Navarro, N., Barron, C., and Duarte, C. M.: Ecosystem metabolism and carbon fluxes of a tidally-dominated coastal lagoon, Estuaries, 27, 977-985, 2004.

Scarratt, M. G. and Moore, R. M.: Production of methyl bromide and methyl chloride in laboratory cultures of marine phytoplankton II, Mar. Chem., 59, 311-320, 1998.

Tait, V. K. D. U.: An investigation of the oceanic source of methyl chloride, Dalhousie University, Halifax, N.S., 1995.

Tait, V. K., Moore, R. M., and Tokarczyk, R.: Measurements of methyl-chloride in the Northwest Atlantic, J. of Geophys. Res.Oceans, 99, 7821-7833, 1994.

Tett, P., Gilpin, L., Svendsen, H., Erlandsson, C. P., Larsson, U., Kratzer, S., Fouilland, E., Janzen, C., Lee, J. Y., Grenz, C., Newton, A., Ferreira, J. G., Fernandes, T., and Scory, S.: Eutrophication and some European waters of restricted exchange, Cont. Shelf Res., 23, 1635-1671, 2003.

Tokarczyk, R. and Moore, R. M.: Production of volatile organohalogens by phytoplankton cultures, Geophys. Res. Lett., 21, 285288, 1994.

Urhahn, T.: Leichtflüchtige ECD-aktive Verbindungen in der marinen Grundschicht ( MBL ) des Atlantischen Ozeans : Vorkommen, Quellen und Verteilung, Department of Analytical Chemistry and Environmental Chemistry, University of Ulm, Ulm, Germany, 2003.

Valtanen, A., Solloch, S., Hartikainen, H., and Michaelis: Emissions of volatile halogenated compounds from a meadow in a coastal area of the Baltic Sea, Boreal Environ. Res., 6095, 1-17, 2009.

Wanninkhof, R.: Relationship between wind speed and gas exchange over the ocean, J. Geophys. Res.-Oceans, 97, 7373-7382, 1992.

Weinberg, I., Bahlmann, E., Michaelis, W., and Seifert, R.: Determination of fluxes and isotopic composition of halocarbons from seagrass meadows using a dynamic flux chamber, Atmos. Environ., 73, 34-40, 2013.

Xiao, X., Prinn, R. G., Fraser, P. J., Simmonds, P. G., Weiss, R. F., O’Doherty, S., Miller, B. R., Salameh, P. K., Harth, C. M., Krummel, P. B., Porter, L. W., Muehle, J., Greally, B. R., Cunnold, D., Wang, R., Montzka, S. A., Elkins, J. W., Dutton, G. S., Thompson, T. M., Butler, J. H., Hall, B. D., Reimann, S., Vollmer, M. K., Stordal, F., Lunder, C., Maione, M., Arduini, J., and Yokouchi, Y.: Optimal estimation of the surface fluxes of methyl chloride using a 3-D global chemical transport model, Atmos. Chem. Phys., 10, 5515-5533, doi:10.5194/acp-10-55152010, 2010.

Yvon-Lewis, S. A., Saltzman, E. S., and Montzka, S. A.: Recent trends in atmospheric methyl bromide: analysis of postMontreal Protocol variability, Atmos. Chem. Phys., 9, 59635974, doi:10.5194/acp-9-5963-2009, 2009.

Zhou, Y., Varner, R. K., Russo, R. S., Wingenter, O. W., Haase, K. B., Talbot, R., and Sive, B. C.: Coastal water source of shortlived halocarbons in New England, J. Geophys. Res.-Atmos., 110, D21302, doi:10.1029/2004jd005603, 2005. 